Uşak Üniversitesi Sosyal Bilimler Dergisi

$2014,7 / 4$

\title{
Eminönü Âşir Efendi Hânı
}

Sedat BAYRAKAL*

\section{Özet}

Aşağıdaki çalışma, Âşir Efendi Hânı'nın rölöve, restitüsyon ve restorasyonuna ilişkin tespit ve önerilerin değerlendirildiği bir ön çalışma niteliğindedir. Restorasyon çalışmalarında yeni bilgi ve bulgulara rastlanılması mümkündür. Âşir Efendi Hanı, İstanbul'un Fatih ilçesinde, tarihi yarımada sınırları içinde ve Eminönü semtindedir. Büyük bir olasılıkla XVIII. yüzyılda yapıldığı anlaşılan hân, XIX. ve XX. yüzyıllarda büyük müdahaleler görmüştür. Ticari faaliyetlerin devam ettiği yapı, Sultan Hamâm Caddesi'nden bakıldığında üç, Âşir Efendi Caddesi'nden bakıldığında ise iki katlı görünmektedir. Bu kot farkı, yapının kuzeybatıya doğru aşırı eğimli olmasının sonucudur. Kot farkına dayanarak, (kısmen) üç katlı hânlar grubuna dahil edilmiştir.

Günümüzde, asli hüviyetinden bir hayli uzaklaştırılmış olan hânın köklü bir restorasyona muhtaç olduğu açıktır. Çalışmada, restorasyona yönelik çalışmalara katkı sağlayacak öneriler bulunmaktadır.

Anahtar Kelimeler: Âşir Efendi Hanı, Şehir İçi Hânları, Ticaret Hânları, Eminönü Hânlar Bölgesi, Tarihi Yarımada, Restorasyon.

\section{Eminonu Asir Efendi Khan}

\begin{abstract}
The following study has the nature of a preliminary study in which determinations and proposals as to survey, restitution and restoration of Âşir Efendi Khân are discussed. It is possible to obtain information and findings in restoration works. Âşir Efendi Khân is situated in Eminönü quarter of the Fatih district of Istanbul within the boundaries of the historical peninsula. The big khân which most likely was built in $18^{\text {th }}$ century has been subject to renovations in the century $19^{\text {th }}$ and $20^{\text {th }}$ centuries. The building where the commercial activities continue seems as a three-story building when viewed from Sultan Hamam Street and as a two-story building when viewed from Âşir Efendi Street. This difference in elevation is due to the excessive slope of the building to the northwest. The building is
\end{abstract}

* Doç.Dr., Uşak Üniversitesi, Fen Edebiyat Fakültesi, Sanat Tarihi Bölümü. 
categorized as three-story commercial buildings considering the elevation difference (partially).

The khân which is a great deal far from its authentic identity clearly is in need of restoration. The study includes recommendations that will contribute to restoration efforts.

Key Words: Asir Efendi Khan, Urban Khans, Commercial Buildings, The Region of Khan in The Eminonu District, The Historic Peninsula, Restoration.

A-Konu: Söz konusu taşınmaz, İstanbul I Numaralı Kültür ve Tabiat Varlıklarını Koruma Bölge Kurulu'nun, 12.07.1995 gün ve 6848 sayılı kararı ile belirlenen Tarihi Yarımada Kentsel ve Tarihi Sit Alanında ve İstanbul IV Numaralı Kültür ve Tabiat Varlıklarını Koruma Bölge Kurulu'nun 11.08.2011 gün ve 4728 sayılı kararıyla, düzeltmelerle uygun bulunan, 1/5000 ölçekli Tarihi Yarımada Koruma Amaçlı Nazım İmar Planı ve İstanbul IV Numaralı Kültür Varlıklarını Koruma Bölge Kurulu'nun 25.07.2012 gün ve 788 sayılı kararıyla uygun bulunan Tarihi Yarımada (Fatih) 1/1000 Ölçekli Koruma Amaçlı Uygulama İmar Planında, 1. Derece Koruma Bölgeleri Sınırları içinde ve Genel Ticaret alanlarında kalan, Gayrimenkul Eski Eserler ve Anitlar Yüksek Kurulu'nun 13.04.1969 gün ve 4553 sayılı kararıla korunması gerekli kültür varlığı olarak tescil edilen, İstanbul I Numaralı Kültür ve Tabiat Varlıklarını Koruma Kurulu'nun 15.01.1996 gün ve 7438 sayılı kararıyla rölöve projesi uygun bulunan, aynı kurulun 25.02.1998 gün ve 9298 sayılı kararıyla da koruma grubu II olarak belirlenen Âşir Efendi Hânı'nın Sanat Tarihi açısından değerlendirilmesi ${ }^{1}$.

B-Tanıtım: Âşir Efendi Hanı, İstanbul'un Fatih İlçesi, Hobyar Mahallesi'nde 2, 22 pafta, 397 ada, 2, 12 ve 17 sayılı parsellerde bulunmaktadır. Hanı, kuzeyden Sultan Hamâm Caddesi, güneyden Âşir Efendi Caddesi kuşatmaktadır. Tarihi yarımada alanı içinde, Osmanlı döneminde olduğu gibi, günümüzde de ticaretin yoğun yaşandığı Eminönü

\footnotetext{
1 Yayın konusunda gösterdikleri anlayıştan ötürü hissedar vekilleri Sayın Cevat Görgülü, Sayın Zeynep Buldan Eyigüngör, Sayın Hacı Ali Akın, Sayın Beklan Binbir, Mimar Sayın Ayşen Yılmaz Öğüt ve Sayın Ali Rıza Öğüt'e ayrı ayrı şükranlarımı sunarım. Paylaştıkları bilgilerden ötürü, Ayşen Yılmaz Öğüt ve Ali Rıza Öğüt'e ayrıca müteşekkirim.

${ }^{2}$ Günümüzdeki Hobyar Mahallesi, Hoca Kasım Günani, Şeyh Mahmud ve Hobyar mahallelerinin birleştirilmesiyle oluşturulmuştur: Benli 2007: 1, dipnot 1.
} 
bölgesindedir. Yığma yapı tekniğiyle inşa edilmiştir. Özel mülkiyetteki yapının hissedar vekilleri Sayın Cevat Görgülü, Sayın Zeynep Buldan Eyigüngör, Sayın Hacı Ali Akın, Sayın Beklan Binbir'dir. Genel hatlarıyla yamuk beşgen planlı olduğu söylenebilir (Şek.1). Bölgede çok sayıda hân vardır (Fotoğraf 1). Âşir Efendi Hânı'nı kuzey ve güneyden kuşatan caddelerin doğuda birbirine yaklaştığı bölgede Germania Hân (Fotoğraf 2) (bugünkü Deutsche Orientbank A.G.), doğusunda ve komşu parselde Suraski Hânı ile Ankara Konya Hânı (Fotoğraf 3), sözü edilen iki caddenin batıda birleştiği noktada ise Âşir Efendi Kütüphanesi (Fotoğraf 4) bulunmaktadır (Şek.2). Hânda, bugün için ağırlıklı olarak tekstil sektöründe faaliyet gösteren esnaf dükkânları bulunmaktadır.

Hânın oturduğu arazi, kuzeybatıya eğimli olduğundan, cepheler arasında önemli kot farklılıkları doğmuştur. Günümüzde, bodrum+zemin+asma+2 kattan oluşan hânın, kuzey cephesinden bodrum kat ve bu cepheye açılan dükkanlara ulaşılırken (Fotoğraf 5), güney cephesindeki girişten doğrudan avluya ulaşılmaktadır. Eğim nedeniyle, dıştan, güney cephesinden bakıldığında iki (Fotoğraf 6), kuzey cephesinden ise üç kat (Fotoğraf 7) görülmektedir (Şek.3-4). Bodrum katta 6 depo; Sultan Hamâm Caddesi'ne bakan (kuzey) cephedeki zemin katta 8 dükkân; asma katta 13 depo; avlu kotundaki birinci katta 21 dükkân, 4 depo, 1 çay ocağı, 1 kapıcı odası olarak kullanılan bölüm; ikinci katta 17 dükkân, 1 depo, 1 oda, 1 lokanta, 1 mutfak ve bay-bayan wc bulunmaktadır. Tüm dükkânların cephelerine asılan reklam amaçlı panolar, bütüne ilişkin algılamayı güçleştirmektedir.

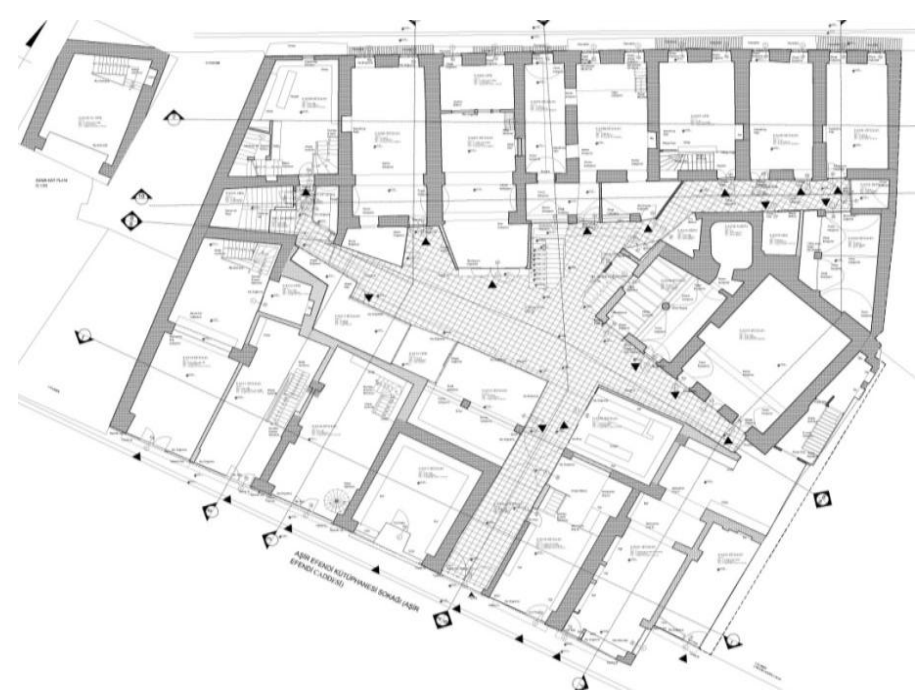

Şekil.1.Rölöve planı (1.kat) (OfisNova Mimarlık'tan). 
S. BAYRAKAL $\mid 120$

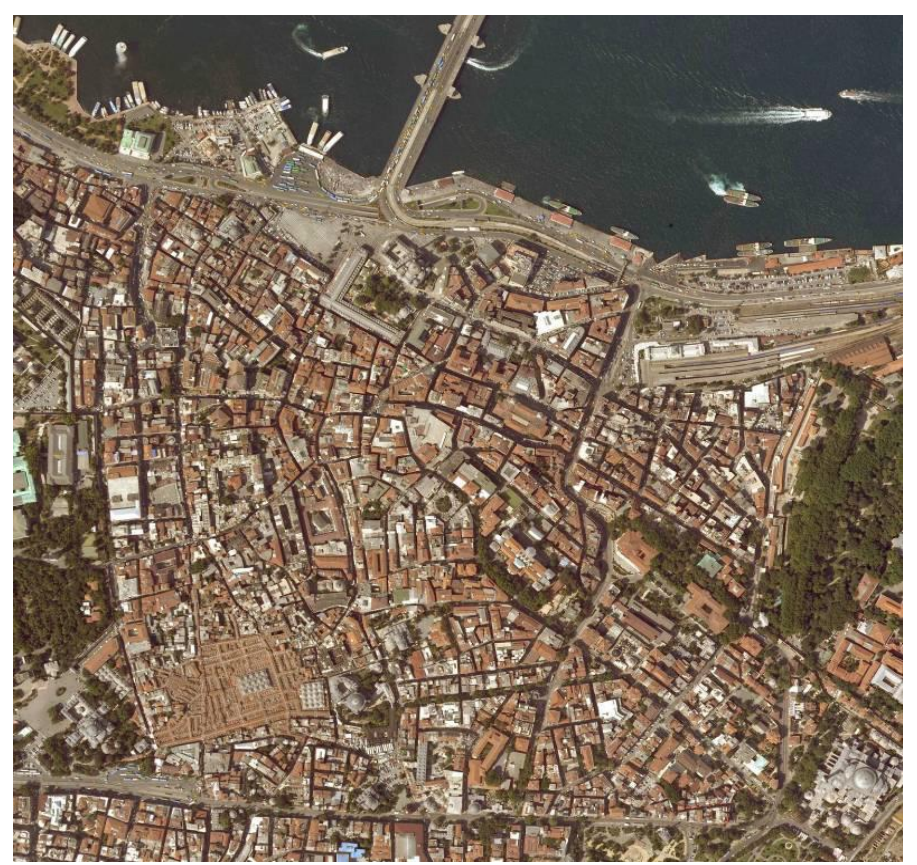

Fotoğraf 1-Eminönü hânlar bölgesini gösteren 2006 tarihli hava fotoğraf (Gülhan Benli 2007, s. 5).
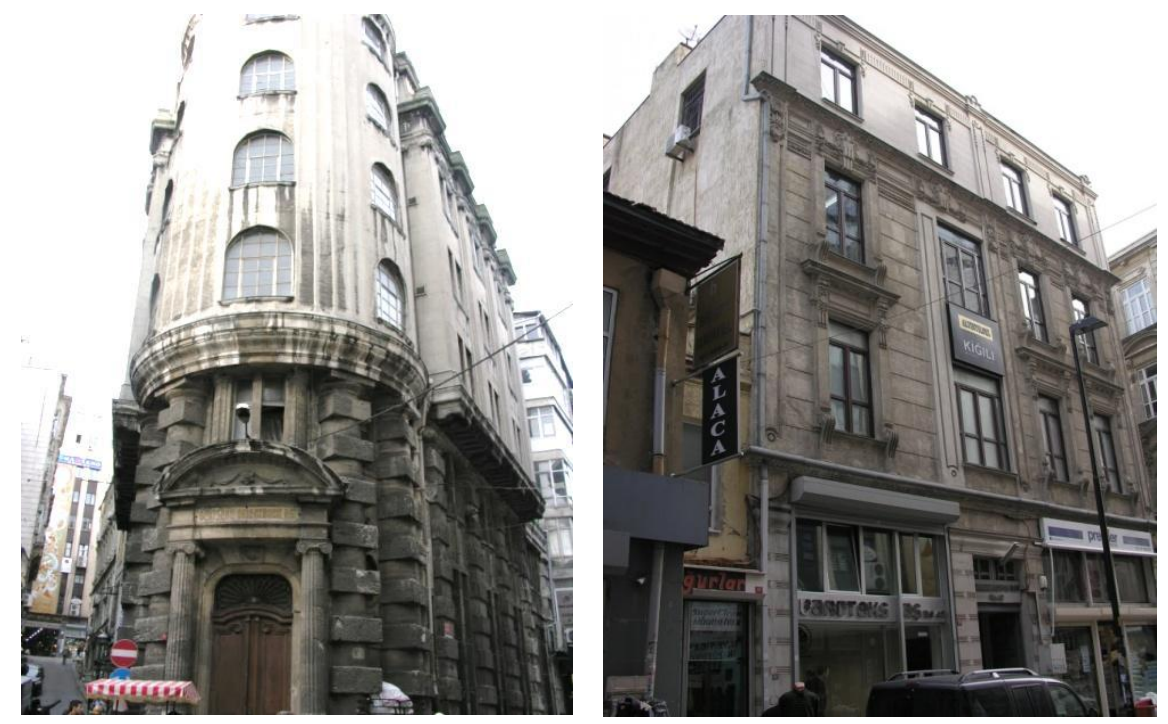

Fotoğraf 2-Germania Hân. Doğu cephesi.

Fotoğraf 3-Ankara Konya Hânı. Güney cephesi. 
Sosyal Bilimler Dergisi 121

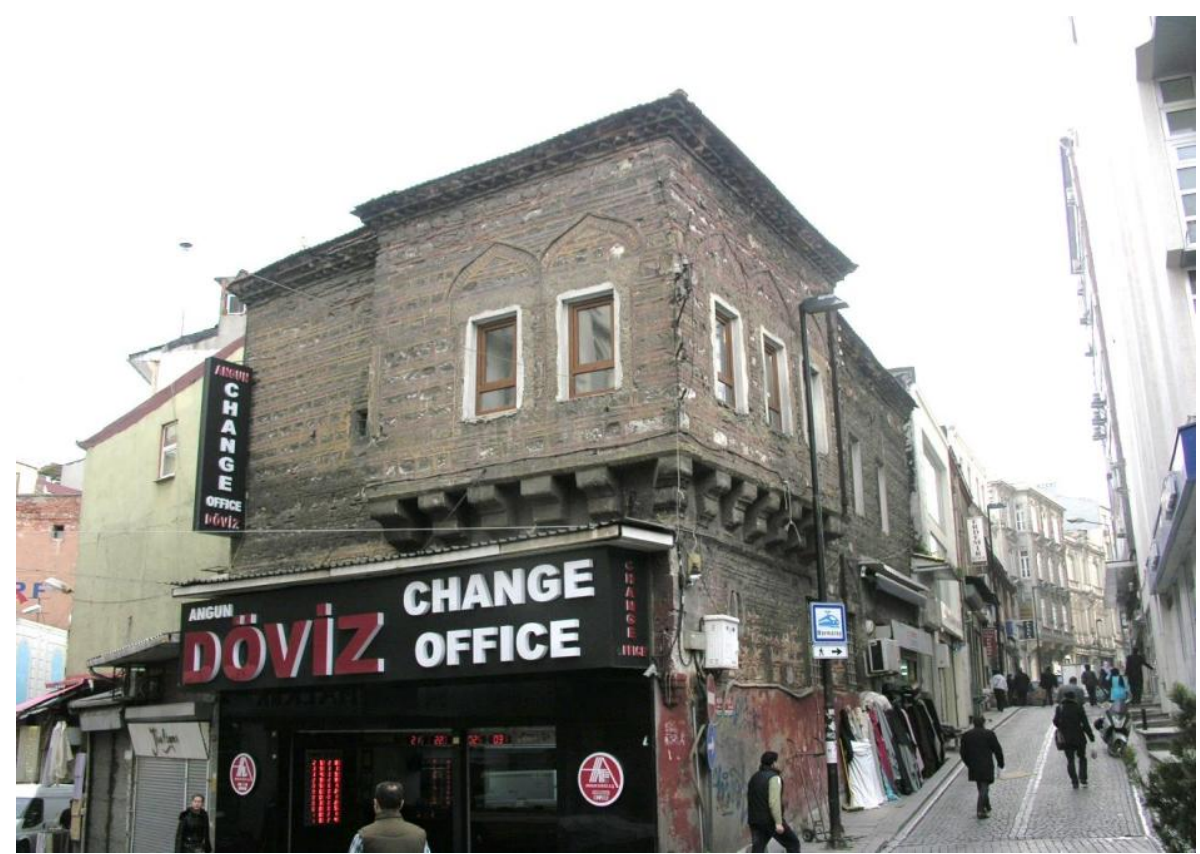

Fotoğraf 4-Âşir Efendi Kütüphanesi. Güneybatı cephesi.

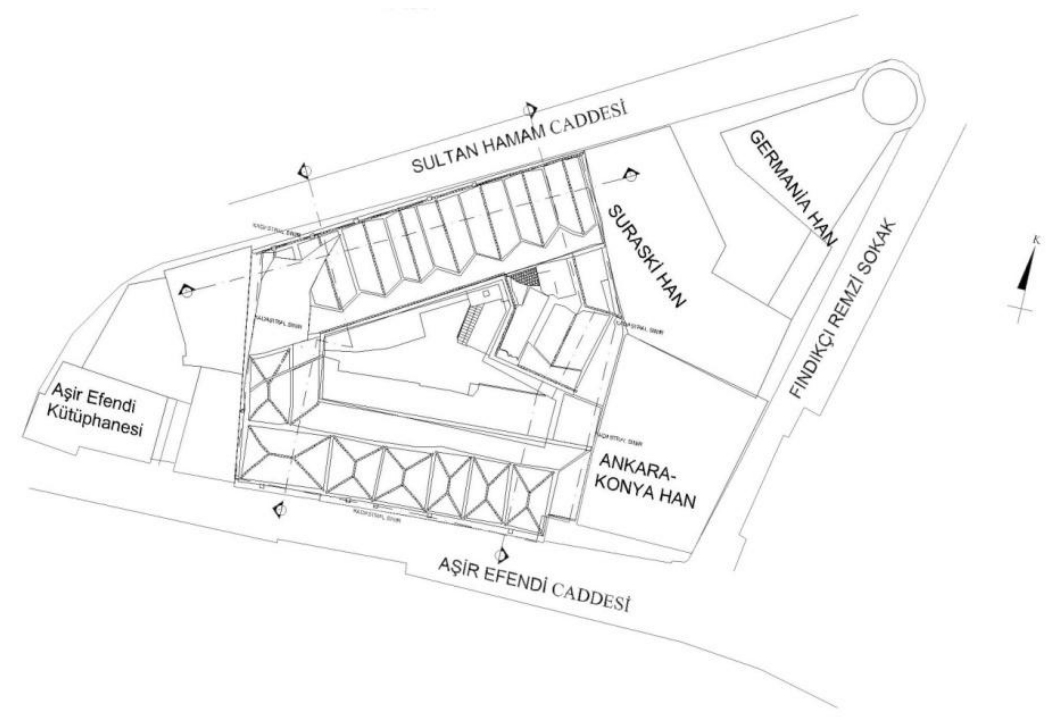

Şekil.2.Vaziyet Planı. 1/200 Ölçek (OfisNova Mimarlık'tan). 
S. BAYRAKAL 122

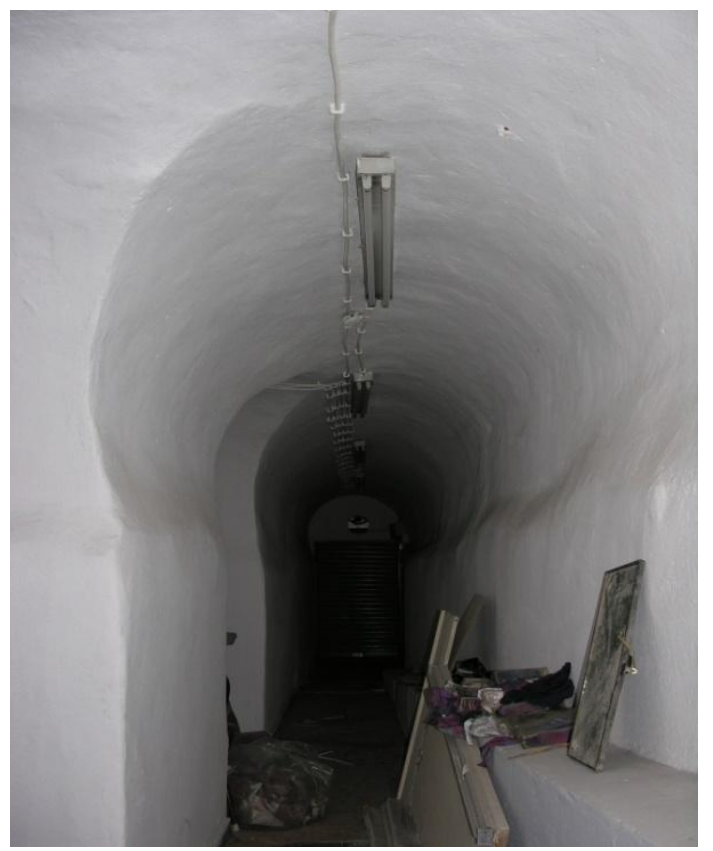

Fotoğraf 5-Bodrum kat koridor ve tonozlarından birisi.

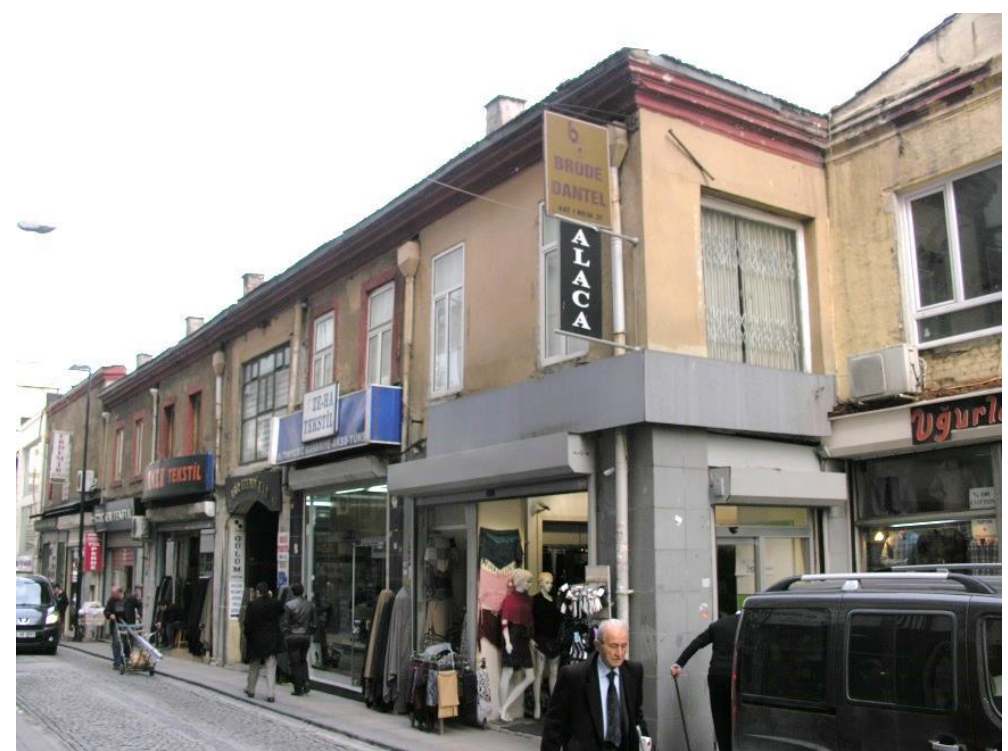

Fotoğraf 6-Güney cephesi. 


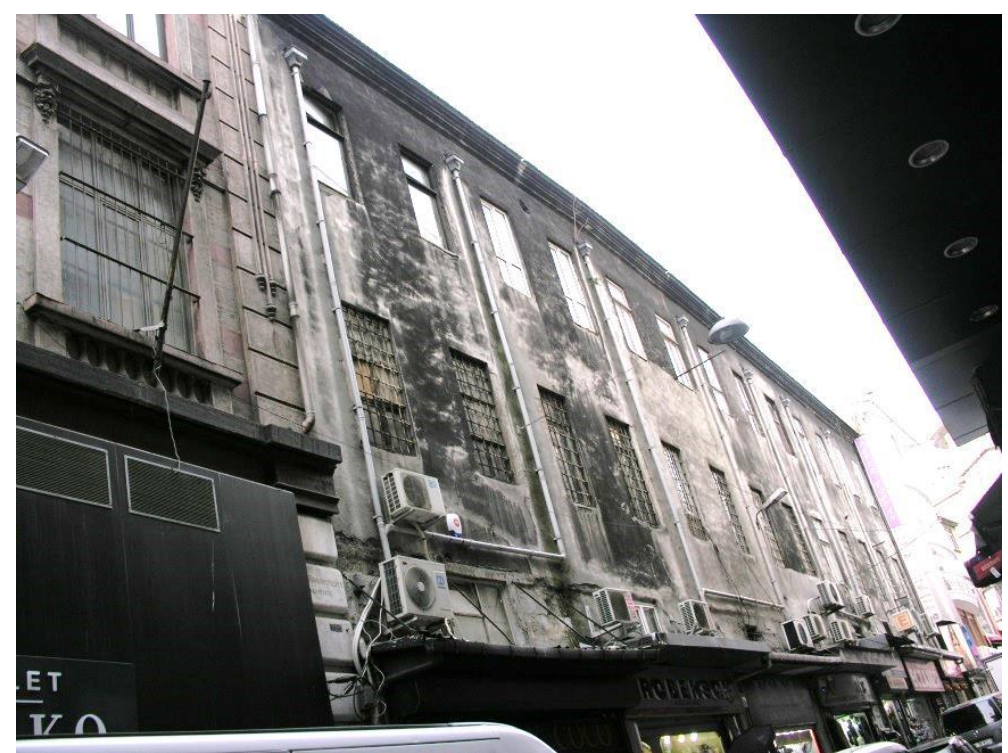

Fotoğraf 7-Kuzey cephesi.

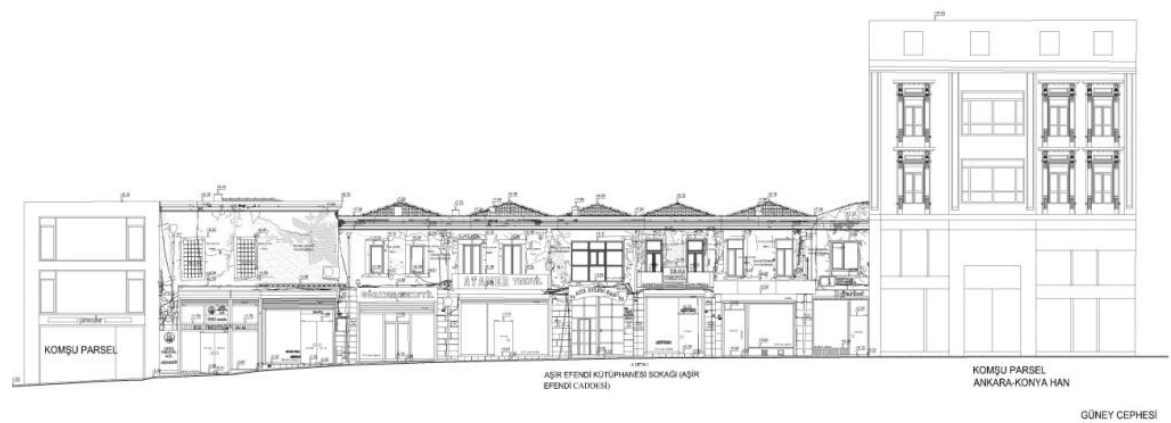

Şekil 3. Güney cephe silueti. 1/50 Ölçek (OfisNova Mimarlık'tan).

Âşir Efendi ve Sultan Hamâm caddelerine bakan cepheler bir hayli müdahale görmüştür. Cephelerin zemin katında pencere bulunmamaktadır³.

Kuzey cephede, zemin kattaki dükkânlar Sultan Hamâm Caddesi'ne açılmaktadır. Genel hatlarıyla sade düzenlenmiş cephenin zemin katında, bugün dükkâna dönüştürülen eski girişin batısında dört, doğusunda üç olmak üzere toplamda yedi dükkân bulunmaktadır. Ancak giriş, dükkânlar arasında neredeyse kaybolmuştur. Her bir dükkânın üstüne denk gelecek

${ }^{3}$ Güran, İstanbul hânlarının zemin katlarında dışa açılan pencere bulunmadığını söylemektedir: Bkz. Güran 1978: 37-38. 
şekilde, küçük ve yatay dikdörtgen şekilli birer pencere açılmıştır. Asma, birinci ve ikinci katlarda, toplam otuzüç pencere açıklığına yer verilmiştir. Ancak kapatılan cephede pencere açıklığı sayılamamıştır. Cephenin, asma kattan itibaren tamamen sıvanması nedeniyle, alttaki taş ve tuğla örgünün üzeri kapanmıştır. İç ve dış bükey silmelerden oluşan saçak hattı, cephe boyunca uzanmaktadır. Yağmur boruları, klimaların dış üniteleri, reklam panoları ve dükkânların sundurmaları, tescilli bir esere yapılan aşırı müdahalelere işaret ettiği gibi, olası bir restorasyon sonrası ortaya çıkarılacak cephenin algılanabilirliğini de bozucu etkiye sahip olacaktır.

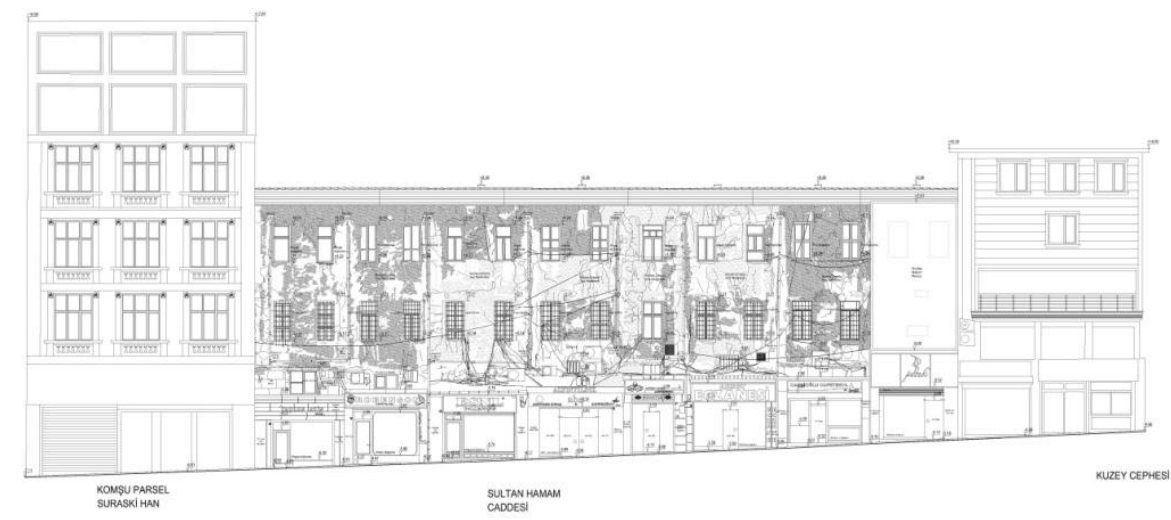

Şekil 4. Kuzey cephe silueti. 1/50 Ölçek (OfisNova Mimarlık'tan).

Âşir Efendi Caddesi'ne bakan güney cephenin tasarımı, kuzeydekinden farklıdır. Zemin kotunun kuzeye göre daha yüksek olmasından dolayı, sadece iki kat görülmektedir (Bkz. Fotoğraf 6). Güney cephesinde en dikkat çekici özellik, cephenin batısındaki iki dükkân ve üç pencereye denk gelen bölümün saçak seviyesinin, doğusundaki saçak hattına göre bir miktar daha yüksek olmasıdır (Fotoğraf 8 , şek.3). Bu uygulama, güney cephesine farklı tarihlerdeki müdahaleyi kanıtlamaktadır. Ayrıca batıdaki saçak profilinin, doğudakine oranla daha dar tutulması da bir diğer kanıt olarak değerlendirilebilir.

Güney cephesinde dikkat çeken ikinci özellik, cephenin, doğuda girişten sonraki ikinci dükkândan sonra üçüncü dükkânın içerlek olarak devam etmesidir. Böylece bu kesime de bir dükkân inşa edilerek, cephe sonlandırılmıştır (Fotoğraf 9). Girişin üst kesimine, diğer dükkânların üst kesimlerinde de görüldüğü gibi pencere açılmıştır. Ancak bu pencere muhdes olmalıdır. Bu cephedeki dükkân sayısı da yedidir. 
Dar iki cadde ve komşu parselde bulunan iki hâna bitişik olan yapı, günümüzde kullanılmaktadır ve özellikle cephelere oldukça müdahale edilmiş durumdadır. Hânın biri kuzeyde, diğeriyse güneyde olmak üzere iki girişi bulunmaktadır. Kuzeydeki giriş bugün dükkânlardan birinin içinde kalmaktadır ve doğrudan bodrum kata açılmaktadır.

Hân avlusuna giriş ise, güney cephesindeki basık kemerli kapıdan sağlanmaktadır (Fotoğraf 10). Girişin üst kesimindeki yatay dikdörtgen şekilli pencere, boyutları itibariyle yadırganmaktadır. Çünkü, girişin iki yanındaki pencereler dikey dikdörtgen şekillidir ve bu pencereye göre oldukça dar düzenlenmişlerdir. Giriş, güney-kuzey yönlü ve tonoz örtülü koridora açılmaktadır (Fotoğraf 11, şek.1). Koridor, basık kemerle yaklaşık olarak ortadan iki bölüme ayrılmıştır. Girişin iki yanındaki dükkânların, koridora açılan girişleri muhdestir (Bkz. Şek.11).

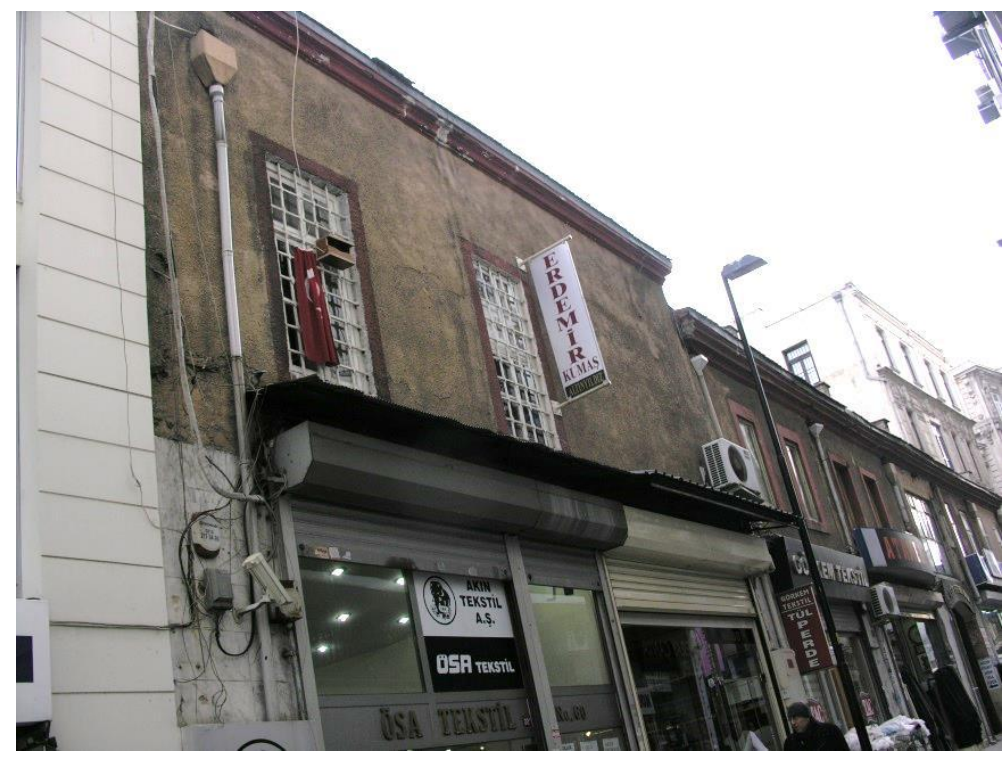

Fotoğraf 8-Güney cephesinin batı kesimi. 


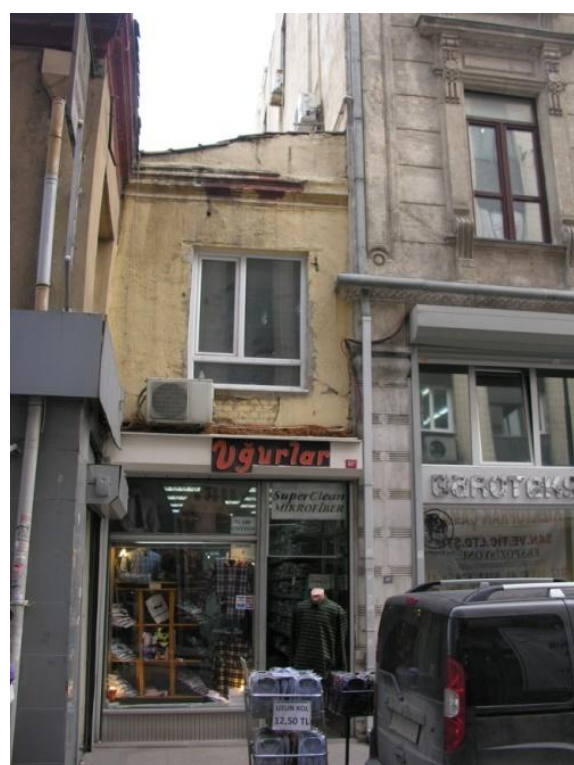

Fotoğraf 9-Güney cephesinin

doğu ucundaki dükkân.

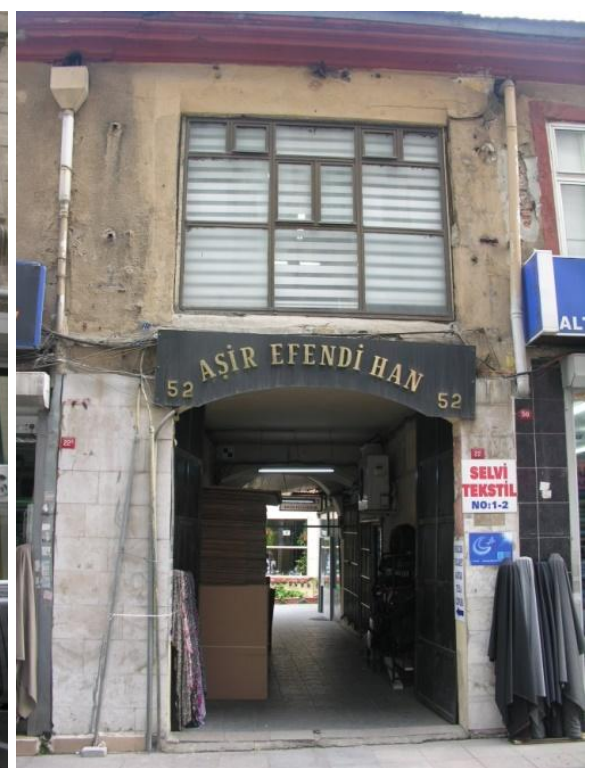

Fotoğraf 10-Güney girişi.

Koridorun kuzey kesiminden avluya geçilmektedir. Avludan, mekanların bulunduğu kesime ilk bakışta bile, yoğun müdahaleyi algılamak mümkündür. Avluya açllan alt kat dükkân önlerinin, alüminyum doğrama camekanlarla doldurularak, kapalı dükkânlara dönüştürüldüğü görülmektedir (Fotoğraf 12).

Üst kata çıkış, avlunun kuzeydoğu kesimindeki tek yönlü ve dönem eki olduğu düşünülen merdivenden sağlanmaktadır (Fotoğraf 13, şek.1). Avluda ayrıca, hâna kuzey dış kesimden girişi sağlayan kapıyla aynı eksende bulunan bir merdiven daha inşa edilmiştir (Fotoğraf 14). Bu merdiven aynı zamanda, zemin kattan avluya girişi de sağlamaktadır. Yenilenen söz konusu merdivenin özgün olduğu anlaşılmaktadır. 
Sosyal Bilimler Dergisi 127

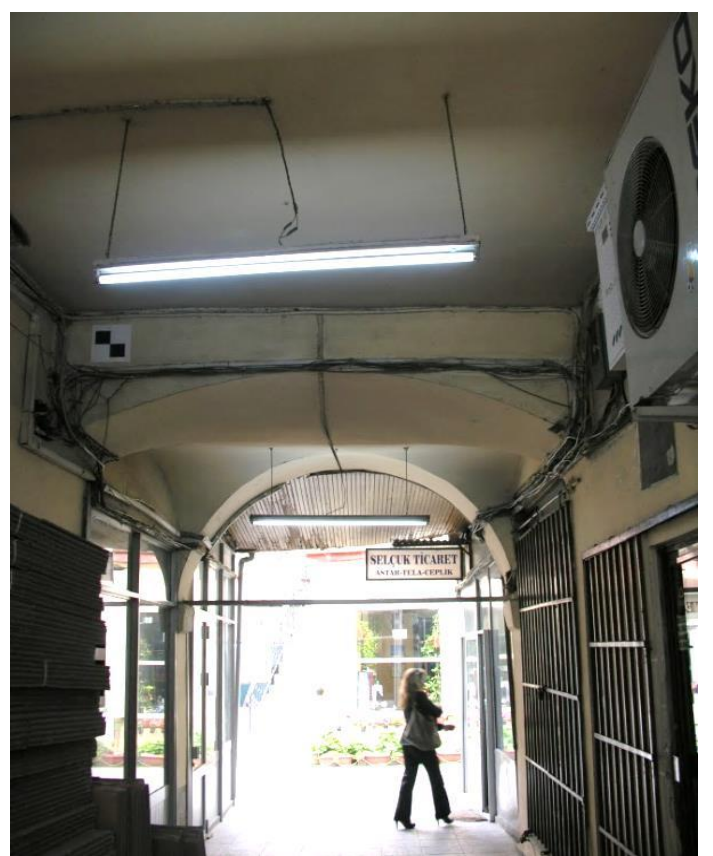

Fotoğraf 11-Avluya geçişi sağlayan güney girişinin koridoru.

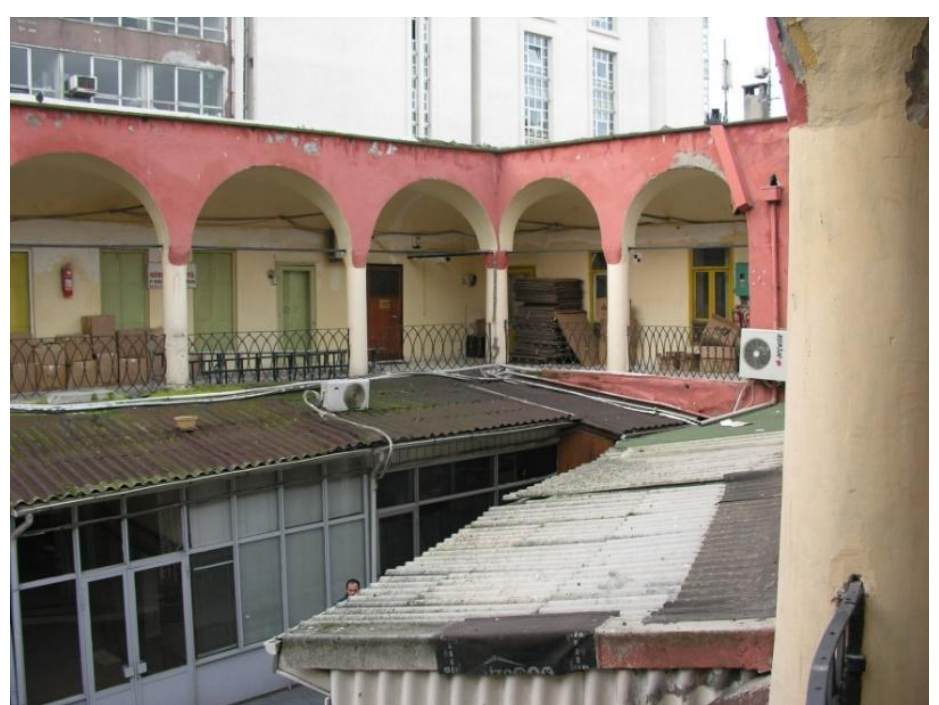

Fotoğraf 12-Avlu güneybatı bölümü. 


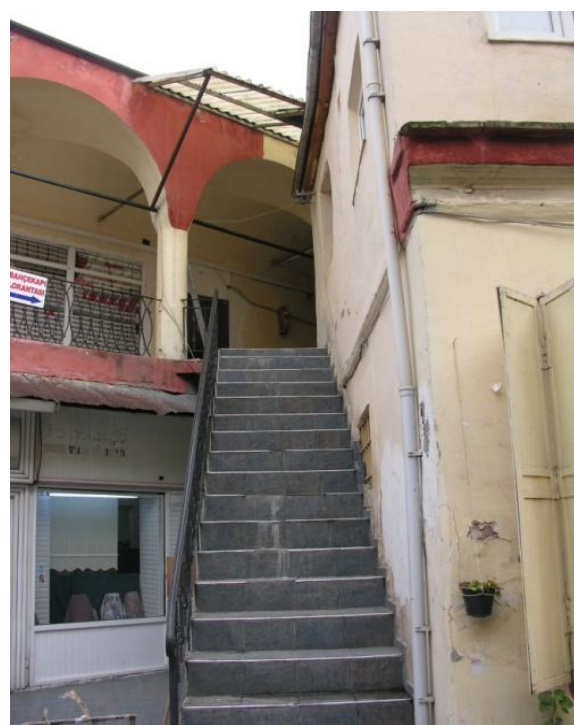

Fotoğraf 13- 2. kata çıkışı sağlayan merdiven.

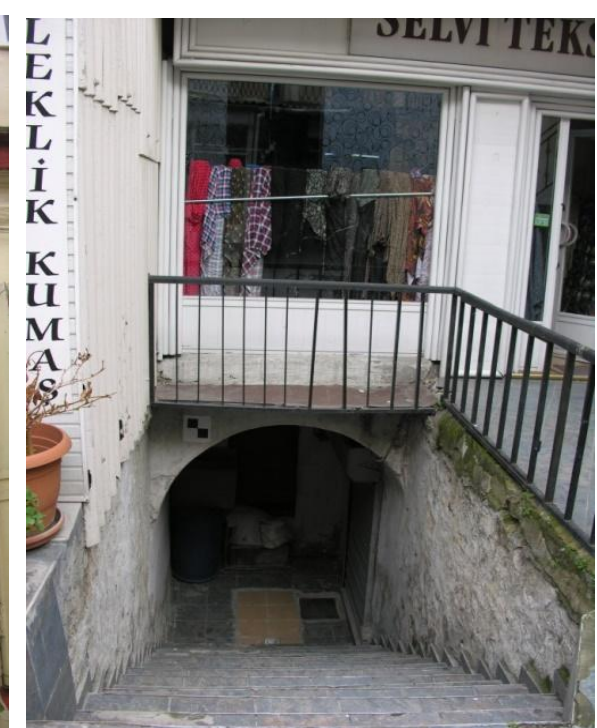

Fotoğraf 14-Zemin kattan avluya çıkışı sağlayan merdiven.

Avlunun kuzeydoğusundaki üç birimli revaklı mekan grubuna batıdan bitiştirilen mekan sonradan eklenmiştir (Fotoğraf 15). Nitekim, ilave edilen mekanın çatı kot seviyesi, orijinal mekanların çatısından daha aşağıdadır.

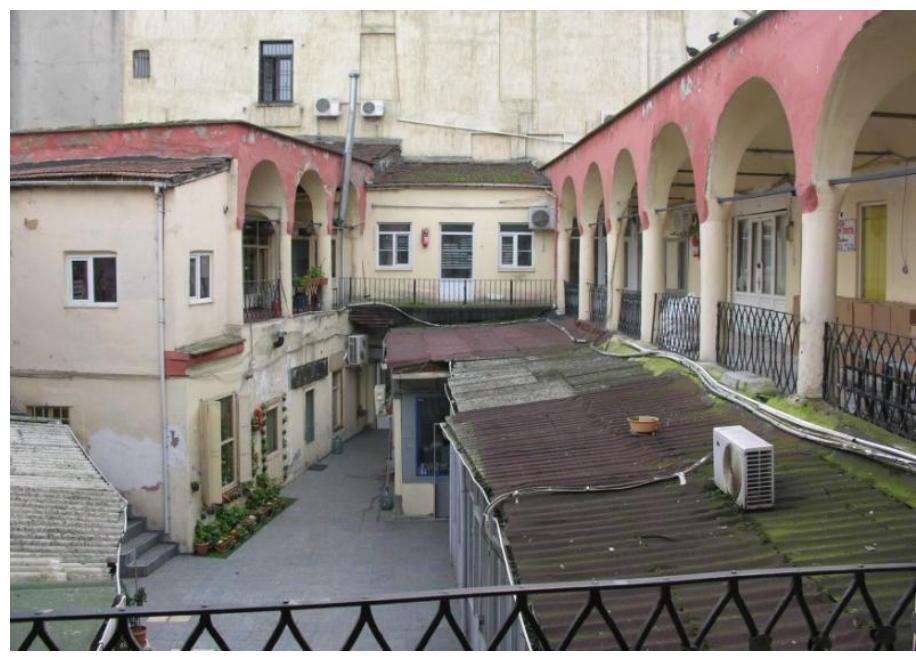

Fotoğraf 15-Avlunun kuzeydoğusundaki mekanlar 
İkinci katın yuvarlak şekilli revak kemerleri, birinci katın daire ve kare planlı sütunlarına oturmaktadır (Fotoğraf 16). Sütun araları demir korkuluklarla kapatılmıştır. Sıva raspaları sonucunda, revak kemerlerinin tuğladan örüldüğü anlaşılmıştır. Bazı sütun başlıkları korinth tipinin sade ve stilize şeklini andırırken, bazıları da yine stilize edilmiş Dor tipini andırmaktadır. Tüm revaklar sıvalı ve boyalıdır.

İkinci katta 17 dükkân, 1 depo, 1 oda, 1 lokanta, 1 mutfak ve 1 baybayan wc'den oluşan 22 mekân bulunmaktadır. Dükkânların kapı kanatları, dışta ahşap camekan, içte dökme demirden olacak şekilde iki kanattan meydana getirilmiştir (Fotoğraf 17).

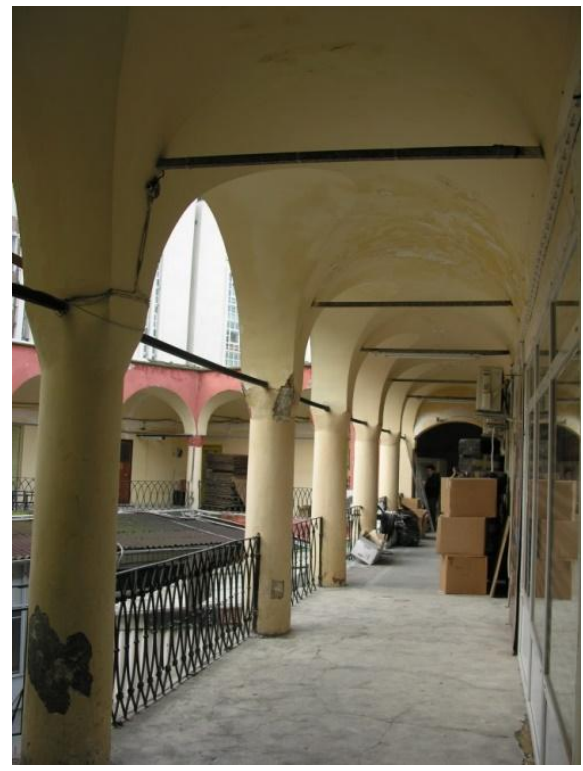

Fotoğraf 16-Kuzey revakı. (2.kat)

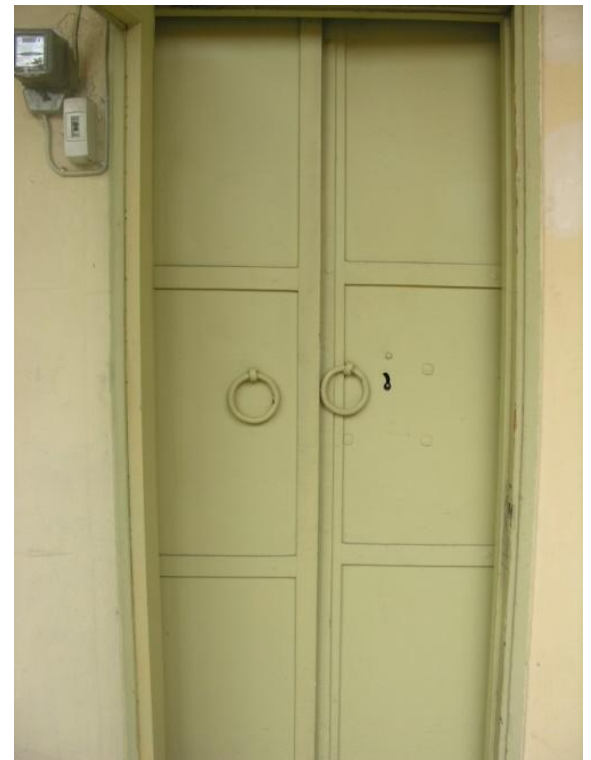

Fotoğraf 17- 2.kattaki dökme demir kapı kanatlarından bir örnek

\section{C-Değerlendirme-Tarihlendirme}

Âşir Efendi Hânı, "Hânlar Bölgesi” olarak bilinen, Eminönü (Fatihİstanbul) semtinde, Hobyar Mahallesi'nde bulunmaktadır. Şehir hânlarının diğer örneklerinde görüldüğü gibi, bulunduğu topoğrafyaya ve parsele uyduğu için kabaca yamuk beşgen plana sahiptir. Yayınlarda pek tanıtılmamakta, sadece adı veya bir fotoğrafıyla geçiştirilmektedir. MüllerWiener, İstanbul'un Tarihsel Topoğrafyası adlı çalışmasının, İstanbul hânlarını işaretlediği haritasında Âşir Efendi Hânı'nı F.6/4 kod numarasıyla vermiştir4.

${ }^{4}$ Müller-Wiener 1998. 
Ayverdi de 19. Asır'da İstanbul Haritası başlıklı çalışmasında, B.4 koduyla haritasına işlemiştir ${ }^{5}$ (Şekil 5). J.J. Pervititch, 1922-1945 yılları arasına ait sigorta haritalarında (Şekil 6) ve yine Goadtary, haritasında Âşir Efendi Hânı'nı da işaretlemişlerdir (Şekil 7). Pamukciyan, alfabetik sırayla yayınladığı İstanbul Hânları listesinde sadece adını vermiştir6.

G. Benli, İstanbul Tarihi Yarmadada Bulunan Hân Yapıları ve Avlulu Hânların Koruma Sorunları, konulu doktora tezinde, İstanbul hânlarını sıraladığı tabloda Âşir Efendi Hânı'na da yer vererek, yapının iki katlı olduğunu belirtir?

C. Güran, Türk Hânları'nın Gelişimi ve İstanbul Hânları Mimarisi adlı kitabında, verdiği 102 İstanbul Hânı arasında ve XV-XVIII. yüzyıllarda mevcut İstanbul hânları içinde Âşir Efendi Hânı'nı tanıtmamaktadır ${ }^{8}$. F. Işıközlü'nün, İstanbul'un Eski Vakıf Hânları başlıklı makalesinde sıraladığı hânlar listesinde de adı yoktur?.

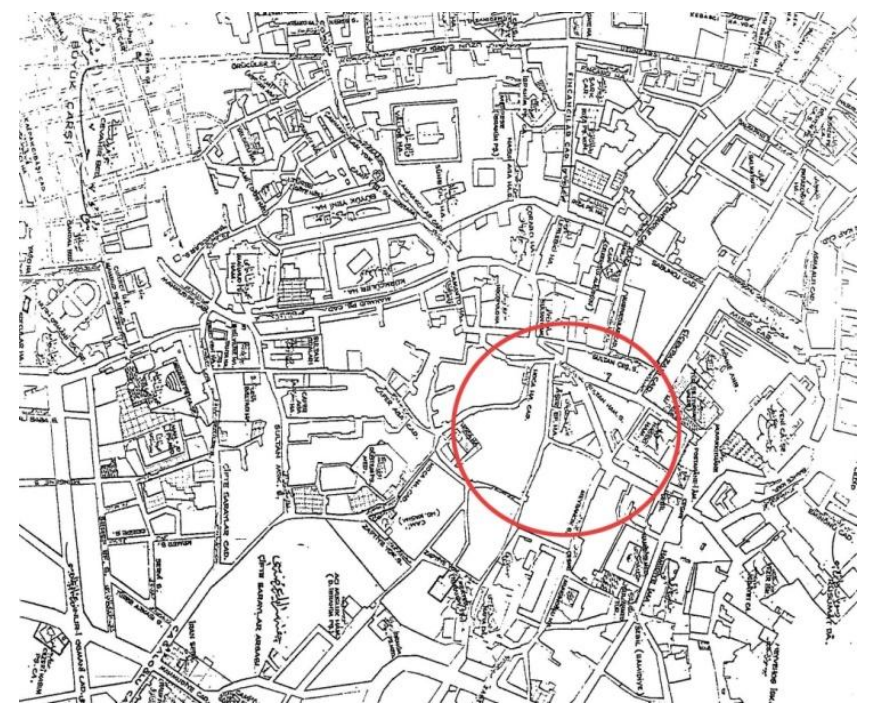

Şekil 5-Ayverdi tarafından 1958 yılında yayınlanan haritada Âşir Efendi Hânı (Bilecik 2004: Ek2, İstanbul Haritaları'ndan).

\footnotetext{
${ }^{5}$ Ayverdi 1958.

${ }^{6}$ Pamukciyan'dan nakleden Benli 2007: 85.

${ }^{7}$ Benli 2007: 91.

8 Güran 1978: 27-28.

${ }^{9}$ Işıközlü 1973: 421-424.
} 


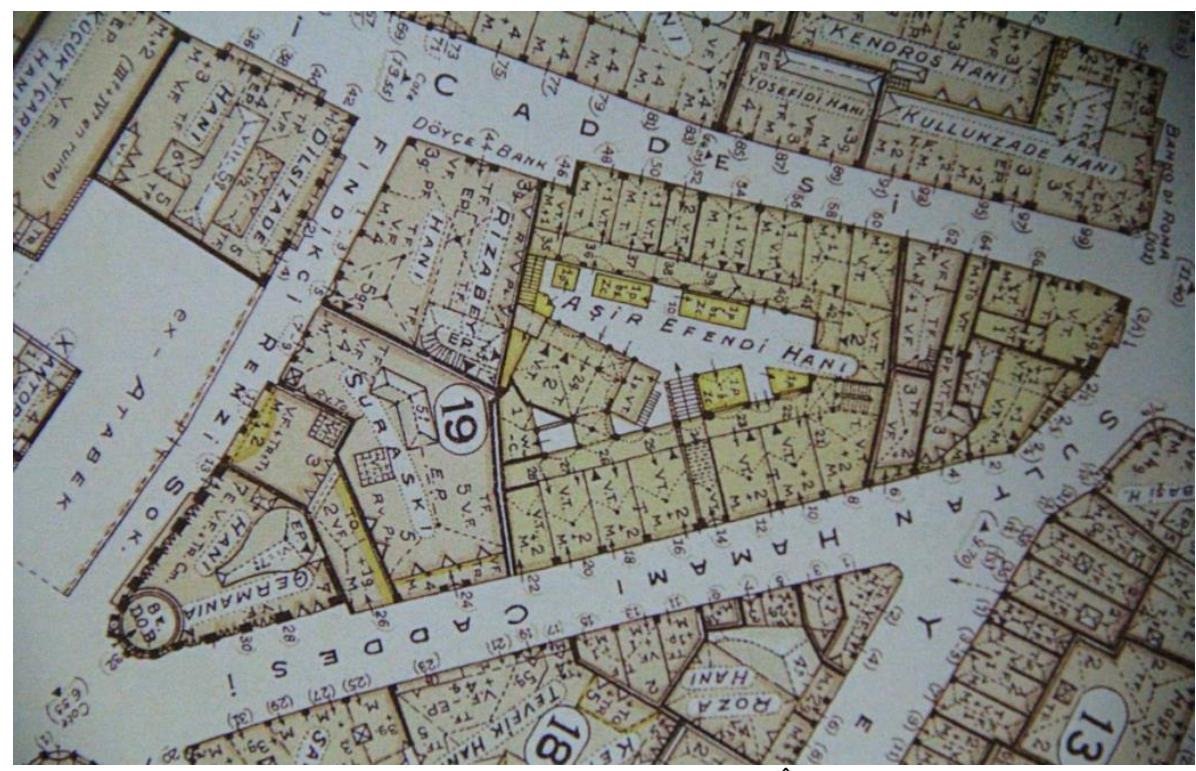

Şekil 6-Pervititch'in 1940 tarihli sigorta planında Âşir Efendi Hânı.

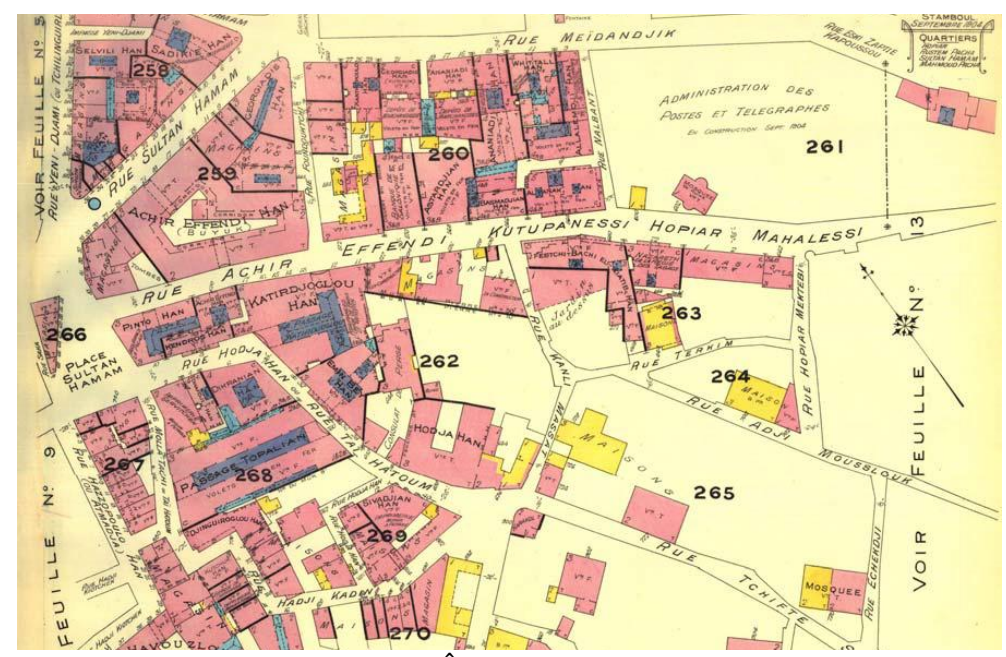

Şekil 7-Goadtary'nin haritasında Âşir Efendi Hânı.

Âşir Efendi Hânı, fonksiyon yönünden, Osmanlı döneminde ortaya çıkan ve Anadolu Selçuklu döneminde görülmeyen Şehir Hânları veya Ticaret Hânları grubundandır. Avlu ve kat sayıları bakımından değerlendirilecek olursa, tek avlulu ve kısmen üç katlı hânlardandır.

Âşir Efendi Hânı'nın inşa kitabesi yoktur. Hân hakkında verilen bilgiler -yukarıda örnekleriyle beraber verildiği gibi- neredeyse yok denecek 
kadar azdır. Genel bir saptama olarak, Osmanlı dönemine tarihlenen şehir hânlarının büyük bir çoğunluğunun inşa kitabesi olmadığg söylenebiliri10. İstanbul'da bulunan hânlar için de bu durum geçerlidir. Burada, yapının Âşir Efendi adıyla anılması, bazı tartışmaları zorunlu hale getirmektedir. Çünkü ne yapıyla ilgili bilgi veren kaynaklarda, ne de Mustafa Âşir Efendi'nin hayat kesiti içinde, yapıyı Âşir Efendi'nin yaptırdığına dair açıklayıcı ve kesin bilgiler bulunmamaktadır. Ancak, Ayverdi'nin yayınladığı XIX. yüzyıla ait haritada (Şekil 5), Pervititich'in 1940 tarihli sigorta planında (Şekil 6) ve Goadtary'nin haritasında (Şekil 7), Âşir Efendi Hânı adıyla tanıtıldığından, hakkında bilgi veren kaynaklarda olduğu gibi, biz de bu ismi benimsedik. Hân'ı kuzey ve güneyden kuşatan caddelerin batıda birleştiği kesimde, aynı adla anılan bir kütüphane bulunmaktadır. Söz konusu kütüphaneyi, I. Mahmud'un resiü'l-küttablarından Mustafa Efendi'nin kendi adıyla yaptırmak istediği, bu amaçla, 1741 ve 1747 tarihli iki vakfiye düzenleterek kitap bağışında bulunduğu belirtilmektedir. Mustafa Efendi'nin 1749'da vefat etmesi üzerine, oğlu Âşir Efendi, Şevvâl 1214/Mart 1800 tarihli vakfiyesiyle kütüphaneyi kurmuştur ${ }^{11}$. A. Budak, kütüphanenin 1741 yllında inşa edildiğini söyler; ancak kaynak belirtmez ${ }^{12}$. S. Eyice, kütüphane ilk yapıldığında, yanındaki büyük bir hânın yapıya gelir sağladığından söz etmektedir ${ }^{13}$. A. Budak da, kütüphane gelirlerinin bitişiğindeki hândan sağlandığını, söz konusu hânın bugün mevcut olmadığını ve yerine başka eserler inşa edildiğini söylemekte; ancak bilginin kaynağını belirtmemektedir ${ }^{14}$. Âşir Efendi Hânı 397 nolu ada üzerinde bulunurken, kütüphane 5 parselde yer almaktadır (Şekil 8). Şu halde, durumu tartışmaya açık olmakla beraber, Âşir Efendi'nin bugün halen ayakta olan kütüphaneyi tamamlattığını, gelirini de yakınındaki hândan sağladığını kabul edebiliriz. Bu bilgilere göre, Âşir Efendi Hânı, kütüphanenin kurulduğu 1800 yılı civarında ayaktaydı. Ancak yine de bu bilgi, hânın ne zaman inşa edilmiş olabileceği sorusunu cevapsız birakmaktadır.

Bu soruya cevap aramak için Âşir Efendi'nin hayat hikayesi irdelenebilir: 5 Ağustos $1729^{\prime}$ da doğan Âşir Efendi, reîsü'lküttab Mustafa

10 Örneğin B. Ersoy, İzmir'deki mevcut şehir içi hânlarının çoğunda kitabe olmadığını; kesin inşa tarihinin tek örnekte bilindiğini belirtmektedir: Ersoy 1991: 5.

${ }^{11}$ Erünsal 1991: 8.

${ }^{12}$ Budak 2006: 211.

${ }^{13}$ Eyice 1991: 8.

${ }^{14}$ Budak 2006: 211. 
Efendi'nin oğludur. 1768'de Yenişehr-i Fenar, 1777'de Bursa, 1781'de Mekke, 1786 'da İstanbul kadılıkları görevinde bulunmuştur. 1788'de Anadolu, bir yıl sonra Rumeli Kazaskeri oldu. Daha sonra azledilerek Kastamonu'ya sürgüne gönderildi. 1791 'de tekrar İstanbul'a dönerek, iki yıl sonra tekrar Rumeli Kazaskerliği'ne atandı. 30 Ağustos 1798'de şeyhü'lislâm oldu. 29 Kasım 1804 tarihinde de vefat etti ${ }^{15}$. İncelediğimiz hânın, Âşir Efendi tarafından yapıldığı kabul edilecek olursa, kendisinin kadılık, kazaskerlik ve şeyhü'lislâmlık yaptı̆̆ 1 XVIII. yüzyılda, İstanbul'da bir hân inşa ettirdiği kabul edilebilir. Yapının XVIII. yüzyılda inşa edilmiş olabileceği saptamasına bir destek de İstanbul'daki üç katlı hânların XVIII. yüzyılda sıklıkla görülmesi eklenebilir16. G. Benli de, çalışma kapsamına aldığı hânları verdiği iki tablosunda da, Âşir Efendi Hânı'nı gerekçe belirtmeksizin XVIII. yüzyıla ait olduğunu söyler ${ }^{17}$. Reiszâde Âşir Efendi'yle ilgili olarak, babasının Kastamonu'da kendi adıyla bir hânın inşasına başladığı, ancak kendisinin tamamlattığ şeklinde bilgiler geçmektedir (Fotoğraf 18). İki sıra tuğla+bir sıra taştan oluşan düzenli bir almaşık örgüye sahip yapı, XVIII. yüzyıl özellikleri taşımaktadır. Kastamonu örneği İstanbul'dakine göre daha özenli ve özelliklerini kısmen de olsa koruyabilmiştir. Dolayısıyla Kastamonu Âşir Efendi Hânı, döneminin özelliklerini İstanbul örneğine göre daha çok yansıtmaktadır.

İstanbul'daki üç katlı örnekler, tarihlendirmeye yardımcı olabilir. Büyük Yeni Hân (iki avlulu) ${ }^{18}$, Küçük Yeni Hân ${ }^{19}$ ve Sümbüllü Hân ${ }^{20}$ bu şemaya örnektirler. Kitabesine göre 1817 tarihli Yıldız Hân, XIX. yüzyılda inşa edilen az sayıdaki hânlardandır ${ }^{21}$. Bir bölümü üç katlı olan ve tek avluya sahip İstanbul Kapalıçarşı bölgesinde bulunan Kalcılar Hânı (XVIII. yy.) da bu grubun önemli temsilcilerinden biridir ${ }^{22}$.

\footnotetext{
${ }^{15}$ Bilgi için bkz. Süreyya 1996: 329-330; İpşirli 1991: 8.

16 Güran 1978: 36, 47, 79.

17 Benli 2007: 91, 108.

18 Tanitım için bkz. Güran 1978: 113-115.

19 Tanıtım için bkz. Güran 1978: 129-131.

20 Tanitım için bkz. Güran 1978: 155.

21 Tanıtım için bkz. Güran 1978: 143-144.

22 Tanıtım için bkz. Güran 1978: 123-124.
} 


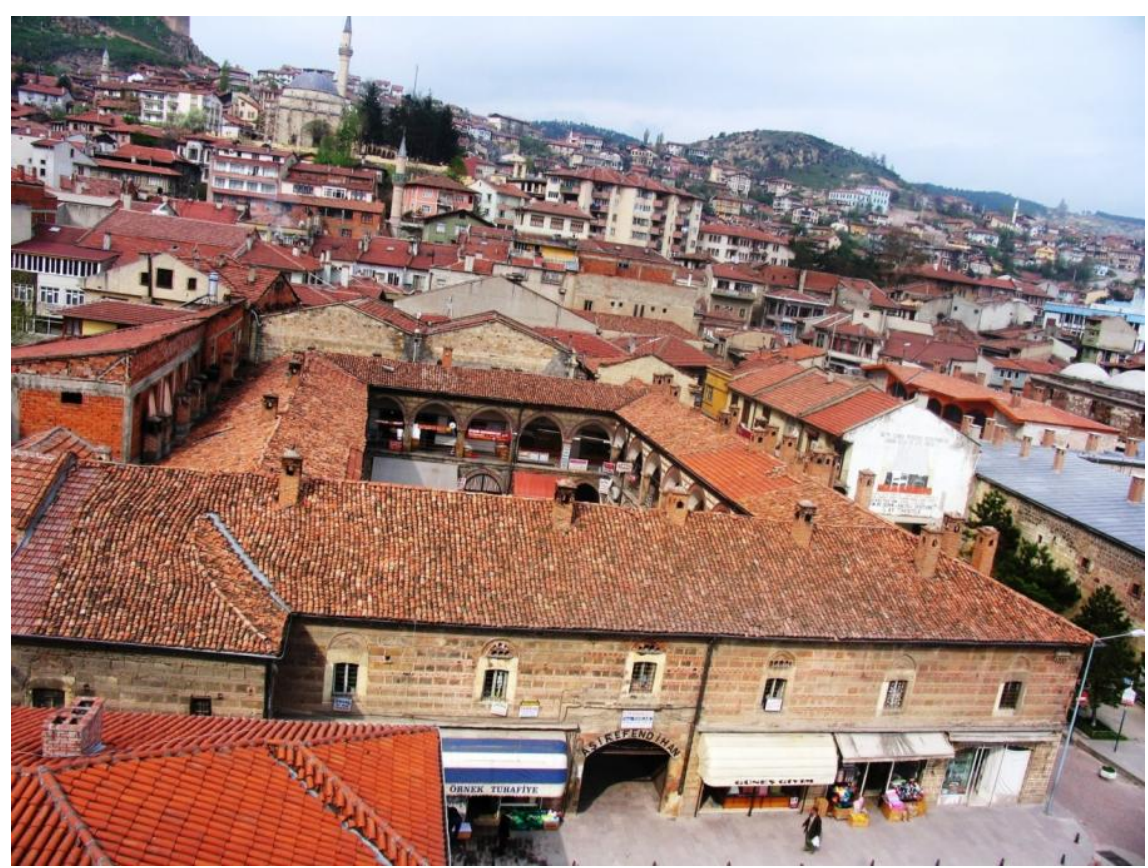

Fotoğraf 18-Kastamonu Âşir Efendi Hânı. Genel görünüş

(http://www.kastamonukonaklari.com/wp-content/uploads/2013/09/asirefendi-hani.jpg)

Sonuç olarak, Âşis Efendi Hânı'nın, Mustafa Âşsir Efendi'nin yaşadığı ve tek avlulu üç katlı İstanbul hânlarının görüldüğü XVIII. yüzyıla ait olduğu düşünülebilir. Ancak yapı bugünkü görünümü itibariyle gerek XIX. yüzyıl, gerekse XX. yüzyıl müdahaleleriyle asli hüviyetinden bir hayli uzak durmaktadır. Kuzey ve güney cephede görülen iç-dış bükey kavisli silmeler, daha çok XVIII. yüzyıl sonu-XIX. yüzyıl İstanbul hânlarında görülen profil örneklerindendir (Fotoğraf 19-20). 


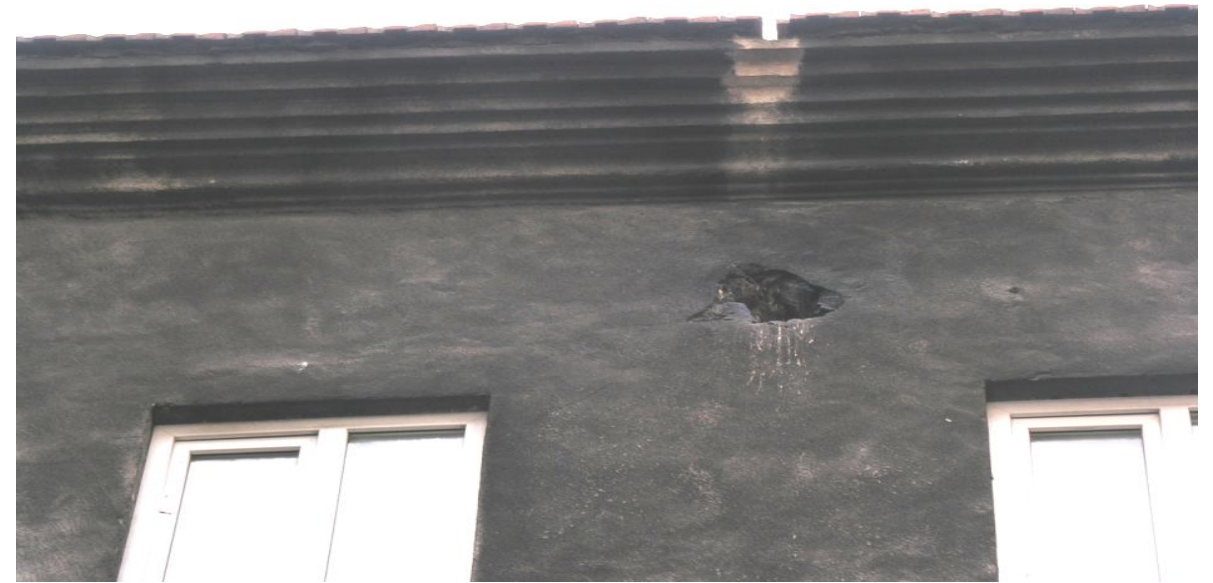

Fotoğraf 19-Eminönü Âşir Efendi Hânı. Kuzey cephedeki silmeler.

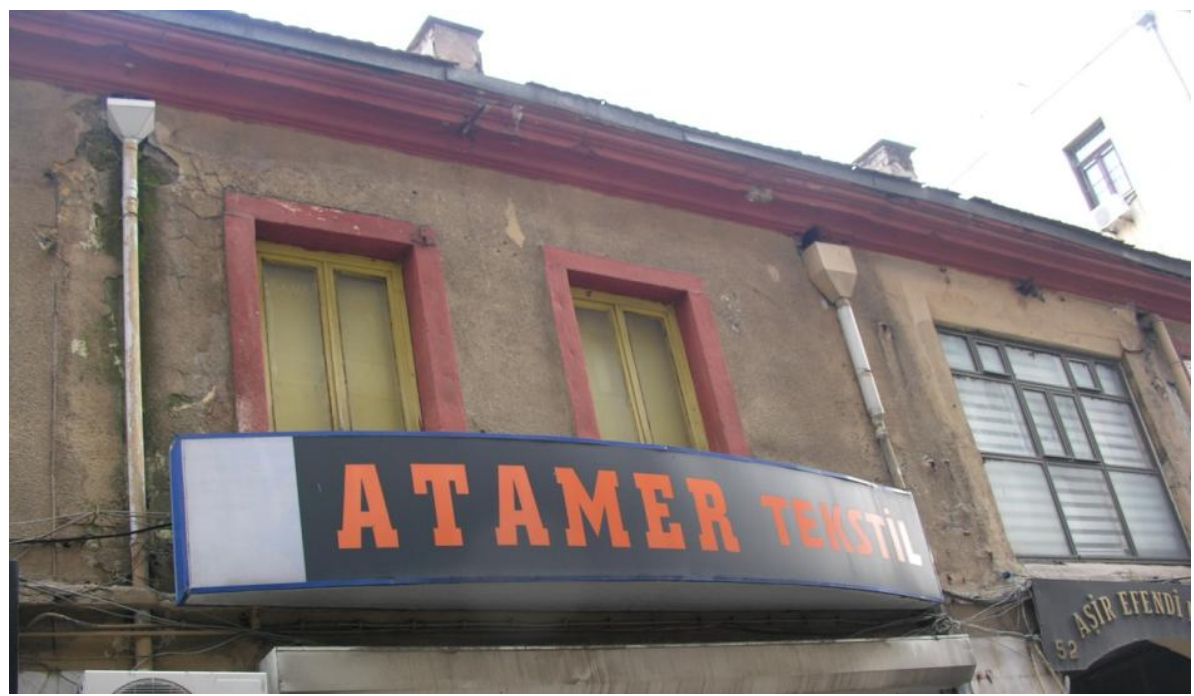

Fotoğraf 20-Eminönü Âşir Efendi Hânı. Güney cephedeki silmeler.

A. Özkan, Eminönü Hânlar Bölgesi'ndeki 11 mahallenin mevcut yapıları ile hânların kat yüksekliklerinin birbirine yakın olduğunu belirtmektedir (Özkan 2003). Buna göre, Âşir Efendi Hânı'nın bulunduğu Hobyar Mahallesi'nde, mevcut hânların kat sayllarının dördün biraz üzerinde, diğer yapıların ise dördün biraz altında olduğunu çubuk grafikle göstermektedir ${ }^{23}$. Yukarıda, kot farkına dayanarak Âşir Efendi Hânı'nın, kuzey cepheden bodrum+asma kat+üç katlı, güney cepheden iki katlı

${ }^{23}$ Özkan 2003: 39, şekil 5.7. Ayrıca bkz. s. 102, şekil E.4. 
olduğu vurgulanmış, yol seviyesinden bakıldığında, güney cephesinden iki, kuzey cephesinden ise üç katlı olduğu ifade edilmişti.

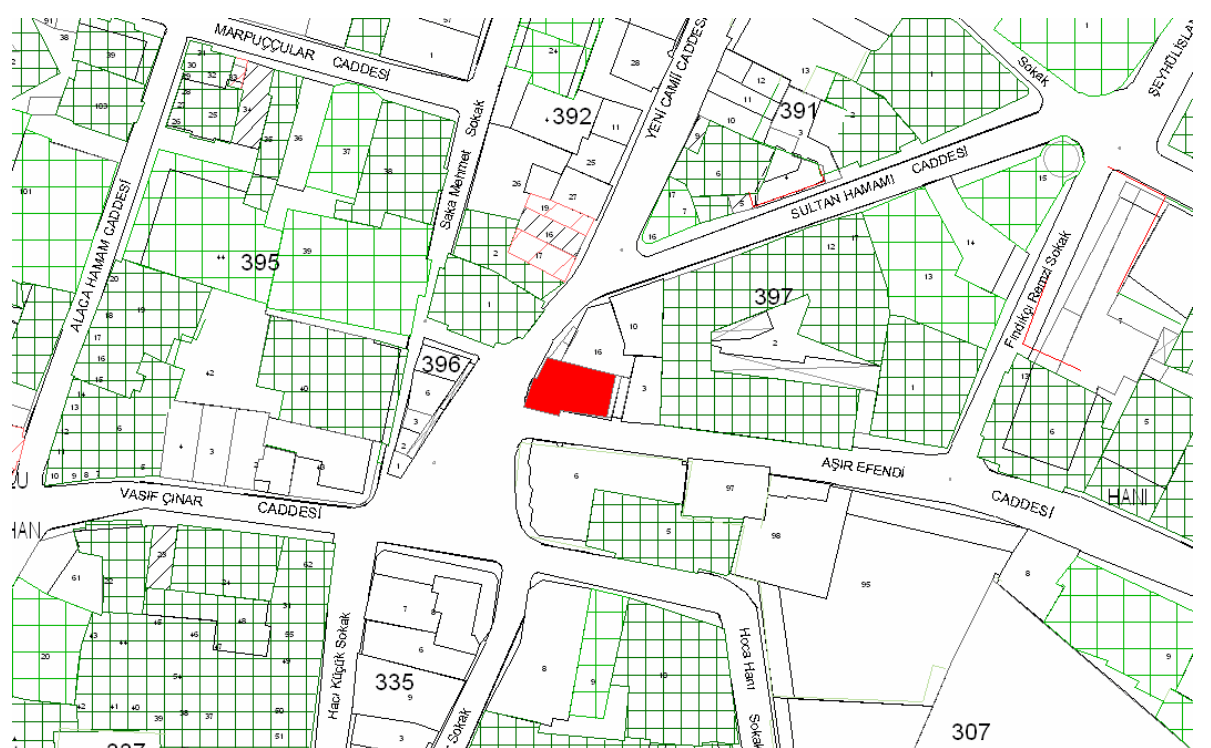

Şekil 8-Âşir Efendi Kütüphanesi ve çevresindeki anıtsal yapıları gösteren vaziyet planı (A. Budak 2006, s.211, şek.29).

\section{D-Rölöve-Restitüsyon-Restorasyona İlişkin Öneriler:}

Hân içinde, rölöve planlarından da görüleceği gibi, çok sayıda muhdes duvar bulunmaktadır. Bu duvarlar, sonradan eklenmiş olsalar bile, dönem eki olarak kabul edilmeli ve tamamen kaldırma konusunda dikkatli olunmalıdır. Çünkü halen çok sayıda bulunan dükkân, depo vb. mekanların ticari işlevleri devam etmektedir. Bir başka deyişle, yapının ilk şeklini alması için gerekli müdahaleler yapılmalı, ancak günümüzdeki ticari faaliyetlerin devam ettiği de düşünülmelidir.

Dükkan ve depoların döşemelerinde yer yer görülen laminat, rabitalar, seramik, granit, marley, karo mozaik, halıfleks, şap, duvarlardaki sıvalar, saten boyalar, alçıpan, alüminyum asma tavanlar, pvc, lambri kaplamalar, duvar kağıtları sonraki eklerdendir.

Âşir Efendi Hânı'nın rölövesinden yola çıkılarak, II. Dönem Restitüsyon ve Restorasyon çalışmalarına kaynaklık ve yardım edecek uygulamalar, aşağıda maddeler halinde sıralanmıştır: 
1) Asma katın (-2.80 kotu) güneybatı köşesindeki depo dönem eki, mekanın doğusundaki depolar ise muhdes ek olarak değerlendirilmelidir (Şek.9, no 1).

2) 1. kat kuzeybatı köşedeki dükkânın kuzey duvarında bugün için görülen bir pencere (Şek.10, no 1), restitüsyon planında iki adet olarak işaretlenmiştir (Şek. 11, no 1).

3) 1. katın güneydoğu köşesindeki dükkânın batı duvarı dönem ekidir. Söz konusu duvar, ilk yapılan duvardan daha ince tutulmuştur (Şek.10, no 2).

4) 1. kat güney cephesindeki dükkânlardan 3 numarayla işaretlediğimiz mekan, kuzeye doğru ilk mekana göre daha fazla uzatılmıştır (Şek.10, no 3). Normalde, kuzey duvarı yan mekan duvarlarıyla aynı eksende olmalıydı. Ayrıca, mekanın kuzey duvarı üzerinde üç açıklığa yer verildiği, restitüsyon planında işaretlenmiştir (Şek.11, no 2).

5) 1. kat güney cephede 4 numarayla işaretlediğimiz dükkânın doğu duvarı, bugün için muhdes ve incedir (Şek.10, no 4)

6) 1. kat batı cephesinin yaklaşık olarak ortasında bulunan dükkânın doğu duvarındaki açıklık (Şek.10, no 5), ikinci dönem restitüsyon planında da işaretlendiği gibi, bir kapı ve üç pencere açıklığına sahip olmalıdır (Şek.11 no 3).

7) 1. katta, özellikle kuzey ve güney kanattaki dükkânların duvarlarından bazıları yıkılarak, yerlerine ahşap ve alüminyumdan ince duvarlar yerleştirilmiştir. Bu konumda olan duvarlar/bölmeler kaldırılarak orijinal duvarlar örülmeli ve bu durum restorasyon projesinde gösterilmelidir.

8) 1. kat tavanlarının sızdırmazlığ malzemeleri kullanmak suretiyle, sızdırmazlık konusunda gerekli hassasiyet gösterilmelidir. 


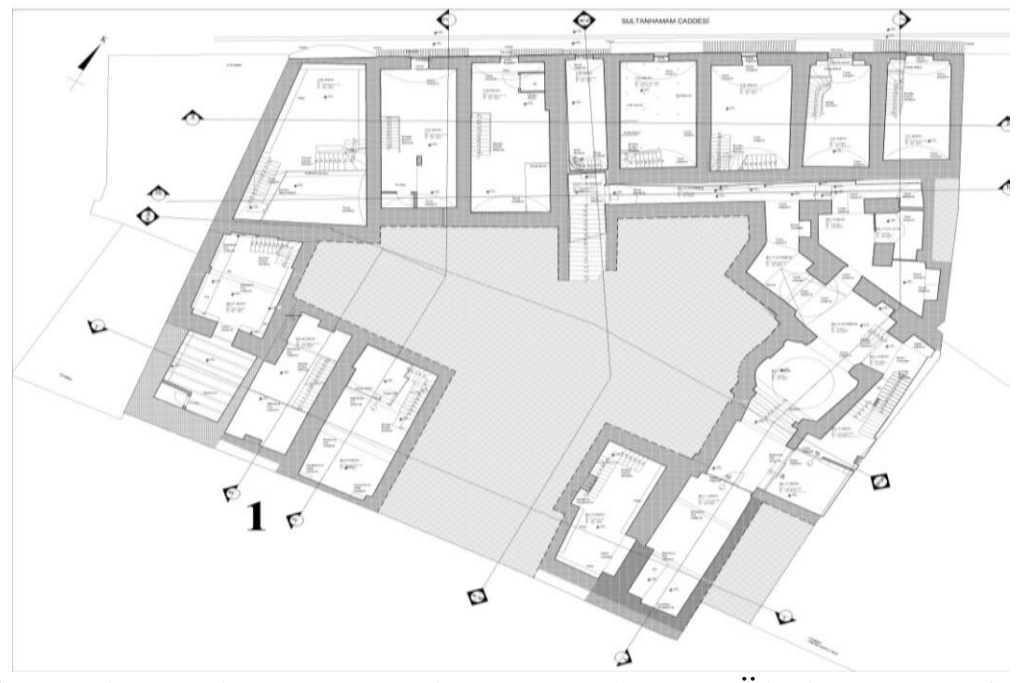

Şekil 9-Rölöve planı (Asma kat, -2.80 kotu). Ölçek 1/50 (OfisNova Mimarlık'tan).

9) 2. kat güneybatı köşedeki dükkânın kuzeydoğusundaki kapı açıklı̆̆ı (Şek.12, no 1), son müdahaleden önce, bir kapı ve bir pencere açıklı̆̆1 şeklinde olmalıydı (Şek.13, no 1).

10) 2. kat kuzeybatı köşedeki dükkânın oldukça müdahale gördüğü anlaşılmaktadır. Mekanın revaka bakan güney duvarında, bugün görülen iki açıklığın (Şek.12, no 2), mevcut izlere göre üç açıklık şeklinde olması gerekmektedir (Şek.13, no 2). Mekanın doğu duvarının güney ucunda bugün görülen açıklık, sonradan açılmıştır. Dolayısıyla söz konusu açıklığın kapatılarak duvara dönüştürülmesi gerekmektedir. Mekanı ikiye bölen duvar da muhdestir. Yukarıda bahsedilen tüm uygulamalar, restitüsyon planında işaretlenmiştir. Ancak ileride yapılacak restorasyon projesi ve uygulamasında dikkate alınmalıdır.

11) 2. katta, kuzey cephesinin yaklaşık olarak ortalarında bulunan ve bodrum merdiveniyle aynı eksende bulunan dar mekanın doğu ve batı duvarındaki kapı açıklıkları (Şek.12, no 3) kapatılarak duvara dönüştürülmelidir (Şek.13, no 3). 


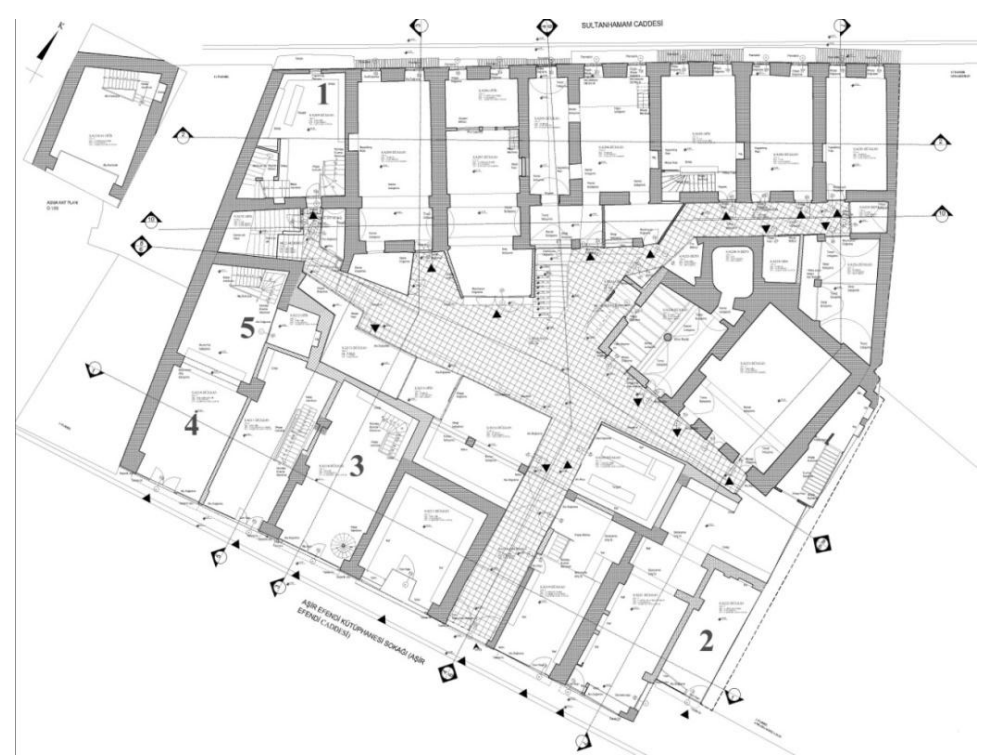

Şekil 10-Rölöve planı (1. Kat, \pm 0.00 kotu). Ölçek 1/50 (OfisNova Mimarlık'tan).

12) 2. kat kuzey cephesinde, rölöve planında 4 numarayla işaretlediğimiz mekanın güney cephesi tamamen dışa açıktır (Şek.12, no 4). Restitüsyon planında da görüleceği üzere, bu kesimde iki açıklı bulunuyordu (Şek.13, no 4). Aynı mekanın doğu ve batı duvarlarının güney ucundaki kapı açıklıkları da kapatılmalıdır.

13) 2. katın kuzeydoğu köşesindeki mekanın revaka bakan duvarında, bugün bir olarak görülen açıklık (Şek.12, no 5), restitüsyon planında belirtildiği gibi, bir kapı ve bir pencere açıklığı şeklinde olmalıdır (Şek.13, no 5).

14) 2. katta yer alan ve bugün lokanta ve mutfak olarak kullanılan 6.35mx6.17m ölçülerindeki dükkânın kuzey duvarındaki bulunması gereken üç açıklık (Şek.13, no 6) bugün için tektir (Şek.12, no 6). Ayrıca, mekanın doğusundaki bugün mutfak olarak değerlendirilen dükkânın (Şek.12, no 7) güney duvarı mevcut değildir. Bu duvarda bir giriş açıklığı bulunmaktadır (Şek.13, no 7).

15) 2. kat güney cephesindeki dükkânlardan doğudakinde, doğu penceresinin genişliği, mekanın diğer pencerelerinden daha fazladır (Şek.12, no 8). Doğu penceresinin ilk inşaatta olmadığı, mekanın doğu duvarın kesintisiz devam ettiği anlaşılmaktadır (Şek.13, no 8).

16) 2. katta, 9 numarayla işaretlediğimiz (Şek.12, no 9) dükkânın kuzeydoğu köşesindeki açılık, mevcut izlere göre nişe dönüştürülmelidir 
(Şek.13, no 9). Zira aksi taktirde, mekanın duvar akışı kesintiye uğramaktadır.

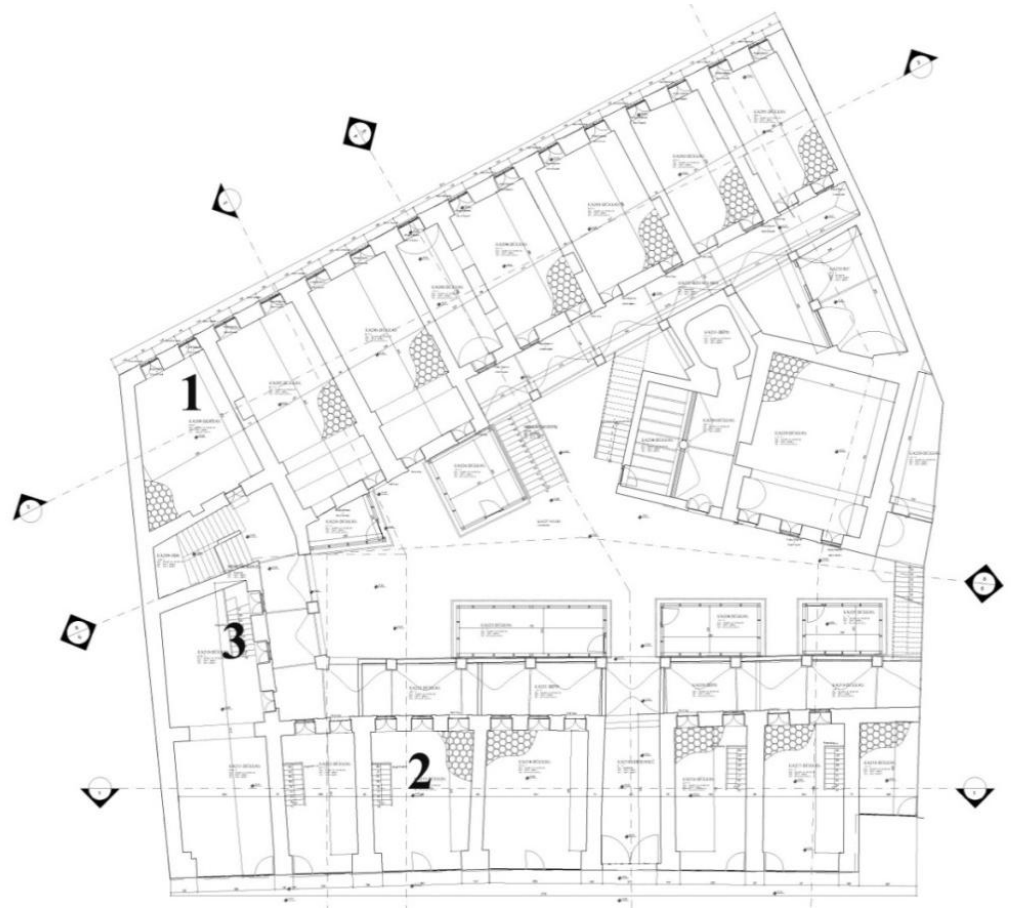

Şekil 11-Restitüsyon 2. dönem planı (1. kat). Ölçek 1/50 (OfisNova Mimarlık'tan). 


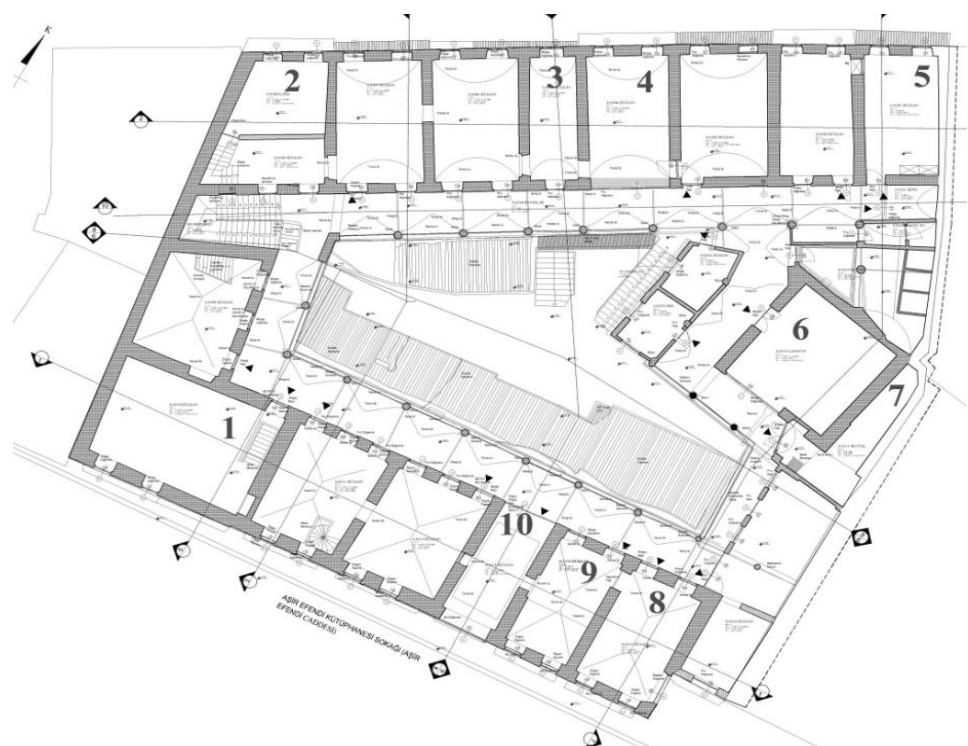

Şekil 12-Rölöve planı (2. kat, +3.45 kotu). Ölçek $1 / 50$ (OfisNova Mimarlık'tan).

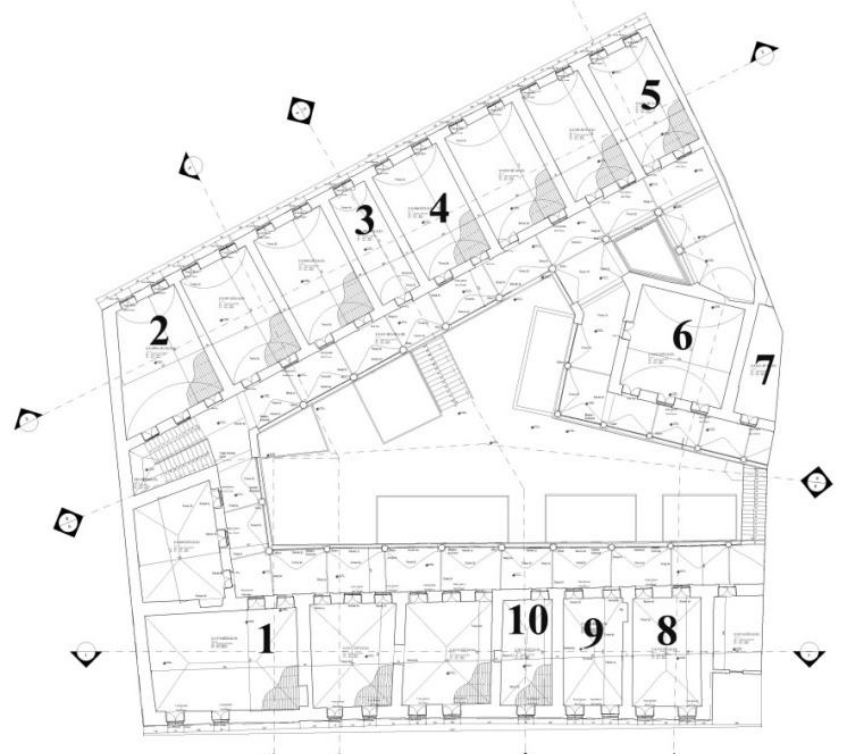

Şekil 13- Restitüsyon 2. dönem planı (2. kat). Ölçek $1 / 50$ (OfisNova Mimarlık'tan).

17) 2. kat güney cephesinde, sağdan veya soldan sayıldığında dördüncü dükkânın giriş açıklığı, bugün mekanın genişliği kadardır (Şek.12, 
no 10). Oysa ki bu kapı açıklığı, diğer dükkânlarda da olduğu gibi, mekanın genişliği kadar olmamalıydı. Bu mekanın batısındaki açılık, bir önceki dönemde niş olmalıdır (Şek.13, no 10).

18) Güney girişinin üst kesimindeki pencere oldukça büyüktür. Diğer pencerelere oranla hayli büyük boyutlardaki bu pencerenin (Bkz. fotoğraf 10), cephenin diğer pencerelerinde de görüleceği gibi, daha küçük boyutlarda olması beklenir.

19) Kuzey cephedeki sıva nedeniyle, taş ve tuğladan oluşan almaşık örgü altta kalmıştır.

20) Yağmur boruları, klimaların dış üniteleri, reklam panoları ve dükkânların sundurmaları, tescilli bir esere yapılan aşırı müdahalelere işaret ettiği gibi, olası bir restorasyon sonrası ortaya çıkarılacak cephenin algılanabilirliğini de bozucu etkiye sahip olacaktır.

21) Restorasyon çalışmaları sırasında, pencerelerin söveleri ile basık kemerlerin ortaya çıkarılmasına dikkat edilmelidir.

22) Güney cephesinin batı kesimi ile doğu kesiminin saçak hatları farklı kotlardadır. Sıva tabakasının kaldırılması sonucu, farklı inşaat aşamalarına dikkat edilmelidir.

23) Avlu zeminindeki dükkânların önlerinde, kapalı mekanlar oluşturmak suretiyle müdahale edilmiştir.

24) II. dönem restitüsyon ve restorasyon çalışmalarına kılavuzluk yapması bakımından, yapının bazı kesimlerinde raspa çalışmaları yapılmıştır. Raspa sonucunda, yapının restitüsyonuna ilişkin önemli sonuçlar elde edilmiştir. Genel bir saptama olarak, Sultan Hamâm Caddesi'ne bakan cephede, pencere kenarlarında yapılan lokal raspa çalışmaları sonucunda, cephenin çimentolu harç ile kaplandığı, kaplamanın altındaki duvarın moloz taş ve tuğlalarla örüldüğü anlaşılmıştır. Aynı dokunun revaklarda da takip edildiği anlaşılmıştır. Revaklardaki sütunların gövdeleri ve başlıkları küfekidir. Gövde ve başlıklar sıvalı ve boyalıdır. Ayaklar üzerinde yapılan lokal raspa çalışmaları sonucunda, sıva tabakasının altından bir sıra moloz taş ve iki sıra tuğladan oluşan almaşık örgü çıkmıştır. Tescilli eser olması bakımından zarar vermemek adına özgün dokuya ulaşılamamıştır. Ancak avlu kotunda bulunan dükkânlardan birinde, taşıyıcı ayak örgüsünün küfeki taş bloklardan oluştuğu, üzerinin sonradan alçıyla kaplandığı ve bir çok kez boyandığı, yerinde yapılan incelemelerde tespit edilmiştir. Revak tonozlarında tuğla kullanılmıştır.

25) Mevcut görünüm, kuzey ve güney revaklarının doğuya devam ettiğini düşündürmektedir. Şüphesiz bugün için, yapıya doğudan yaslanan 
Ankara Konya Hânı'nın bulunması nedeniyle, bu yargıyı kanıtlayacak verilerden yoksunuz. İstanbul'a büyük kayıplar veren 1894 depreminde, Kapalıçarşı'daki 18 hân ile bu civarda bulunan hânların büyük bir kısmının yıkıldığı belirtilmektedir. Ticaret merkezi zamanla, Mahmutpaşa yokuşunun altından Sultan Hamâm'a kaydırılarak, bu bölgede yeni hânlar yaptırılmıştır24. Depremden sonra, Âşir Efendi Hânı'nın da kısmen yıkılarak tahrip olduğunu, Ankara Konya Hânı'nın cephe özelliklerine ve yol kotunun üzerinde dört katının bulunmasına dayanarak, XX. yüzyıl özellikleri taşıması nedeniyle, söz konusu depremden sonra, Âşir Efendi Hânı'nın tahrip olan kesimlerinin kaldırılarak bu alana, Ankara Konya Hânı'nın inşa edilmiş olduğunu düşünüyoruz.

26) Güney kanadın dört, kuzey kanadın ve avlunun doğusundaki mekanlar grubunun iki, revakların tek yana eğimli kırma çatılarını kaplayan Marsilya tipi kiremitler kontrol edilmeli, kırılan ve çatlayanlar varsa değiştirilmelidir.

\section{Kaynakça}

Akozan, Feridun (1963): Türk Hân ve Kervansarayları, İstanbul.

Ayverdi, Ekrem, Hakkı (1958): 19. Astrda İstanbul Haritası, Fetih Cemiyeti Yayınları, İstanbul.

Benli, Gülhan (2007): İstanbul Tarihi Yarımadada Bulunan Hân Yapıları ve Avlulu Hânların Koruma Sorunları, Yıldız Teknik Üniversitesi, Fen Bilimleri Enstitüsü, Mimarlık Anabilim Dalı, Rölöve-Restorasyon Programı, Yayınlanmamış Doktora Tezi, İstanbul.

Bilecik, Gülberk (2004): Ayverdi Haritası'nın Işı̆̆ında XIX. Yüzyılda İstanbul'un Tarihi Yarımadasında İnşaat Faaliyetleri, İstanbul Üniversitesi Sosyal Bilimler Enstitüsü, Sanat Tarihi Anabilim Dall, Yayınlanmamış Doktora Tezi, İstanbul.

Budak, Asuman (2006): 18. Yüzyıl Tarihi Yarımada (Eminönü-Fatih) Kütüphane Yapıları Koruma Sorunları ve Önerileri, Mimar Sinan Güzel Sanatlar Üniversitesi, Fen Bilimleri Enstitüsü, Restorasyon Yenileme ve Koruma Programı, Yayınlanmamış Yüksek Lisans Tezi, İstanbul.

Ergin, Osman, Nuri (2013): Türkiye'de Hânlar, Kervansaraylar, Oteller ve Çeşitli Barınma Yerleri (Yay. Haz. Müslüm Yılmaz), T.C. Marmara Belediyeler Birliği Yayını, Yayın No:78, İstanbul.

\footnotetext{
${ }^{24}$ Ergin 2013 (Yay. Haz. M. Y1lmaz): 75-76.
} 
Ersoy, Bozkurt (1991): İzmir Hanları, Atatürk Kültür Merkezi Yayını, Ankara.

Erünsal, E. İsmail (1991): "Âşir Efendi Kütüphanesi", Türkiye Diyanet Vakfi İslam Ansiklopedisi, 4. cilt, Ankara: 8.

Eyice, Semavi (1991): “Âşir Efendi Kütüphanesi" (Mimari başlı̆ğ altında)", Türkiye Diyanet Vakfı İslam Ansiklopedisi, 4. cilt, Ankara: 8.

Fidan, M. Sadettin (2009), Geçmişten Günümüze İstanbul Hanları, İstanbul.

Güran, Ceyhan (1978): Türk Hanlarının Gelişimi ve İstanbul Hanları Mimarisi, Vakıflar Genel Müdürlüğü Yayınları, İstanbul.

Işıközlü, Fazıl (1973): “İstanbul'un Eski Vakıf Hanları”, Vakıflar Dergisi, sayı X, Ankara: 421-424.

İpşirli, Mehmet (1991): "Âşir Efendi", Türkiye Diyanet Vakfi İslam Ansiklopedisi, 4. cilt, Ankara: 8

Müller-Wiener, Wolfgang (1998): İstanbul'un Tarihsel Topoğrafyası, (Çev: Ülker Sayın), Yapı Kredi Yayını, İstanbul.

Özkan, Alev (2003): Eminönü Hânlar Bölgesinin Cumhuriyetten Günümüze İzlenen Değişimi ve Yeniden Değerlendirilmesinde Öncelikli Bölgenin Saptanması, İstanbul Teknik Üniversitesi, Fen Bilimleri Enstitüsü, Yayınlanmamış Yüksek Lisans Tezi, İstanbul.

Pamukciyan, K (1994): “1868'de Mevcut İstanbul Hânları" Tarih ve Toplum, sayı 128, İstanbul.

Pervitıtch, J.J. Pervititch Haritaları, Milli Reasurans, İstanbul.

Süreyya, Mehmed (1996): Sicill-i Osmanî, 1. cilt, Yay.Haz. N.Akbayar, Eski Yazıdan Aktaran S.A.Kahraman, Tarih Vakfı Yurt Yayınları, 30, İstanbul. 